\title{
Urban Geology for the Enhancement of the Hypogean Geosites: the Perugia Underground (Central Italy)
}

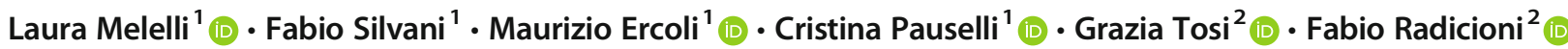

Received: 18 September 2020 / Accepted: 29 January 2021/Published online: 17 February 2021

(C) The Author(s) 2021

\begin{abstract}
Urban geology analyses natural risks and promotes geoheritage in urban areas. In the cities, characterized by a high cultural value, the hypogean artificial cavities, often present in the downtown, offer a unique opportunity to show the geological substratum. Moreover, these places could be a point of interest in urban trekking with the abiotic component of the landscape as a topic (geotourism). To investigate these areas, rigorous bibliographic research and a geomorphological assessment are the first steps, but, besides, non-invasive methods are new techniques increasingly in demand. In this paper, we present a multidisciplinary study on the Etruscan Well (third century B.C.), one of the most important Etruscan artefacts in Perugia (Umbria region, Central Italy). The characteristics of the sedimentary deposits outcropping along the perimeter walls have been collected. Moreover, to show the underground geoheritage, we provide a $3 \mathrm{D}$ model of the well and the surrounding area integrating a georeferenced laser scanner survey with ground-penetrating radar prospecting. We aim to obtain a tridimensional mapping of accessible internal rooms to depict the geological characteristics of the Etruscan Well, also revealing a surrounding network of buried galleries. The results are not only a meaningful advancement in the archaeological, geological and historical knowledge of the downtown of Perugia but are a hint for the geoheritage promotion and dissemination, providing images and 3D reconstruction of underground areas.
\end{abstract}

Keywords Urban geophysics $\cdot$ Urban geology $\cdot$ Geoarchaeology $\cdot$ Geoheritage $\cdot$ Perugia

\section{Introduction}

The iconic image of geology as a science brings to mind natural environments where the human presence is generally absent: this approach is confirmed by the geological research which often had, as areas of investigation, little or no anthropized contexts. Nevertheless, a new trend in the geological exploration of urban areas is growing focused on both risk and resources assessment (Legget 1969, 1973; Karrow and White 1998; Bathrellos 2007). A large number of works are focused on natural hazard and deriving risks for human life, building heritage, infrastructures and productive structures. The geological hazard in anthropized area ranges includes

Laura Melelli

laura.melelli@unipg.it

1 Department of Physics and Geology, University of Perugia, via A. Pascoli s.n.c., 06125 Perugia, Italy

2 Department of Engineering, University of Perugia, via G. Duranti 93, 06125 Perugia, Italy endogenous factors such as the seismic hazard (Zheng et al. 2020) or volcanic one (Carlino 2019) to the exogenic geomorphic processes. Phenomena, as flooding on coastal areas (Siegel 2020) or along rivers (Liu et al. 2020), are enormously increased by climatic change (Blöschl et al. 2019; Chaparro 2020). Finally, landslide events (Mateos et al. 2020) may affect a vast number of human settlements limiting or preventing urban sprawl.

Even if the geological approach to the investigation in urban areas was limited to the natural risks affecting populated areas, one of the most promising challenges is to create a storytelling of the "site history before the human history". Starting from the comprehension of the initial geomorphological arrangement and the successive evolution of the areas coupled with the geological underground characteristics, complete knowledge of the reasons that encouraged the first humans to choose the city's foundation site can be achieved. Generally, these indications are limited to the historic city centres which can be considered as precious records for the urban geological investigation (see some examples in Huggenberger and Epting 2011; Gisotti 2016). These areas 
generally correspond to the initial settlement site, where the choice of the location satisfied some elementary and essential needs, including the possibility of being protected from external aggressions and, at the same time, having easy mobility and commercial communications with the neighbouring territories. Furthermore, the choice of the settlement site was also conditioned by the possibility of using surface and underground waters and mineral resources too (Rosenbaum et al. 2003). These necessary settings, combined with other facilities such as favourable climatic conditions or soil fertility, are all the consequence of the geological setting of a place (Gisotti 2016). The topographic conditions (steep slopes corresponding to natural defence barriers or, conversely, flat areas facilitating the development of communication networks) are the first expression of geomorphological modelling. The underground water reserves, as well as the presence of springs and rivers, are present only if the geological structures allow the development of aquifers. Mining resources, useful for the construction of buildings or artefacts or production of energy, are strictly dependent upon the nature of rocks outcropping out in the area. As a matter of fact, the geological setting is the fundamental factor for the settlement of ancient cities (Legget 1969, 1973; Bathrellos 2007; Gisotti 2016; Marker 2016). Knowing the geological elements, as type and distribution of rocks, and the past and actual geomorphological evolution is fundamental to understand the subsequent development of the urban areas, not only in the past centuries but also nowadays.

One of the most evident limits in the geological and geomorphological investigation of the historic centre is the intense transformations to the previous morphology. Besides, the successive man-made adjustments have further altered the natural conditions, and rebuilding each step is often unachievable without a multidisciplinary approach.

Moreover, due to the almost total absence of lithological surface outcrops and the huge anthropic modifications of the morphology, the collection of geological data is not an easy task (Melelli 2019). A unique opportunity is provided by the artificial hypogean cavities (Parise et al. 2013), which sometimes can occupy the subsoil of the old towns (Melelli et al. 2016; Reynard et al. 2017; Bizzarri et al. 2018; Habibi et al. 2018). The tunnels, often with rooms opening along the track, offer perimeter sides with good height and different orientations with respect to the north direction. Secondarily, the geotechnical investigations, as excavation, dredging, coring or penetrometer tests, if correctly collected in a georeferenced database, can be added to the underground cavities in providing valuable information for the geological assessment (Thornbush 2015; Luberti et al. 2018, 2019; Andersen et al. 2020). These spaces perform different functions such as wells for groundwater storage or drains to facilitate the underground flow, food remittances, air-raid shelters or, for the most ancient ones, as burial graves. In some cases, current underground sites were originally located above the topographic surface and, only subsequently, were buried due to anthropogenic fillings. Nevertheless, these sites are a unique opportunity to rebuild the changes to the initial morphology.

Moreover, the urban geomorphology works in the time frame of the Anthropocene (Lewin and Macklin 2014; Luberti and Del Monte 2020), being the most meaningful to understand the connection between human presence and natural location. Several Italian study cases have been already investigated (Del Monte 2016, 2017; Del Monte et al. 2016; Brandolini et al. 2017; Reynard et al. 2017; Melelli 2019; Cappadonia et al. 2020). Each cavity records the construction techniques or the lifestyle habits of the civilizations that made it. For this reason, these sites may be defined as archaeo-geosites or "any archaeological site where the stratigraphic or geomorphological surrounding conditions are relevant for understanding the geological framework of the site" (Melelli et al. 2016).

In addition, a geological approach to the urban underground may be employed not only for technical purposes but also for the geoheritage enhancement (Palacio-Prieto 2014; Doyle 2016; Zagozdzon and Zagozdzon 2016; Brandolini et al. 2018; Habibi et al. 2018). These places may be the point of interest of urban tourist itineraries (such as geotouristic, i.e. Rodrigues et al. 2011; Dowling 2013; Pica et al. 2016, 2018; Kubalíková et al. 2020), allowing the visitors to have a different perception of urban spaces both in time (the "site history before the human history") and in space (the "upside down 4th dimension" under our feet). Nevertheless, some of these cavities are not always accessible. In fact, these structures are often placed in private properties or their original access routes were buried by subsequent urban changes. Therefore, in such cases, a multidisciplinary approach for their investigation and promotion is necessary. One of the mandatory conditions is that, to preserve the urban heritage, the acquisition instruments and techniques utilized to acquire data should be non-invasive.

Geomatics, as a combination of geodesy and geoinformation, appears as one of the most successful methods. The great and heterogeneous number of spatial data present in a city requires a geographical approach where the whole dataset should be georeferenced and overlaid with great accuracy and resolution. This solution allows a hierarchical representation of the different information, both geological and anthropic ones, with application-oriented modelling (Toschi et al. 2017; Hasan and Hazem 2020; Kumar and Singh 2020).

A fundamental contribution to this approach can also be provided by the geophysical investigations, which might add an additional layer to this kind of representation, which is otherwise not achievable from the surface investigations. Therefore, especially when buried galleries and rooms or the inner sides of the studied targets are inaccessible, the geophysical techniques are the only ones that can be used to acquire 
further information. Particularly common in archaeological and urban applications are techniques like the geoelectrical investigation (Meju 2000) or ground-penetrating radar (GPR) prospections (Basile et al. 2000; Nuzzo et al. 2002; Leucci and Negri 2006; Gizzi et al. 2010; Trinks et al. 2010; Malfitana et al. 2015; Alsharahi et al. 2019; Ristic et al. 2020) or microgravimetry methods (i.e. Butler 1984; Slepak 1997; Sarlak and Aghajani 2017). However, in the lucky cases where such cavities can be partially explored, the integration of techniques like the laser scanner (LS) with GPR has the potential to provide complete and detailed 3D models of a study site (Conejo-Martin et al. 2015; Puente et al. 2018), also allowing quantitative mapping and stability analysis (Ercoli et al. 2016). Such studies not only lead to considerable benefits in terms of conservation strategies but also aim at promoting significant cultural heritage sites. Recently, the use of modern tools based on the exploration of 3D data like augmented and virtual reality (Malfitana et al. 2015; Cencetti et al. 2019; Melelli 2019) may represent additional opportunities to disseminate such information promoting virtual touristic tours (see as example http://www.silenepg.it/visite-virtuali/).

In this paper, we propose a multidisciplinary approach for the investigation of the hypogean geosites in urban areas. The test area is Perugia City (Umbria, Central Italy) and, in particular, the Etruscan Well, one of the most important hypogean archaeological heritages present in the downtown. In order to put in evidence the geological properties of the well and of the entire area, the area surrounding the well has been investigated with different tools and methods. The integration of a geological and geomorphological overview of the area, framed in the wider context of the Perugia hill, with non-invasive investigation methods has been applied to this study case. The result is not only a complete geological and geomorphological description of the site but also a unique opportunity to add the Etruscan Well in the cultural hypogean heritage of the city.

\section{The Study Case of Perugia (Umbria, Central Italy): Geological and Geomorphological Setting}

In this paper, the study case is an Etruscan Well present in Perugia, the capital city of the Umbria region (Central Italy, Fig. 1). The city is located on the top of a hill that reaches the maximum altitude of $493 \mathrm{~m}$ a.s.1., triangular shaped with the apex toward north and spreading out downstream fading into the alluvial deposits of the Tiber River, and divided into five branches by as many small rivers. The hill (Fig. 1) is mainly composed of fluvial and lacustrine deposits dated from upper Pliocene to Pleistocene and with a variable thickness (from a few dozens to a few hundred metres) only occasionally interrupted by the outcropping of a terrigenous complex (marl and sandstone, Burdigalian-Tortonian).
Perugia was a city strongly conditioned by the geology and the geomorphology of its location, even if the same limits are the intrinsic reason of the attractiveness of its urban landscape. The narrow and suggestive valleys, the breath-taking panoramas that can be observed from the belvedere of the historical centre, the arrangement of squares and monuments, everything is a consequence of the effort that men have made over the centuries to adapt the city to the geological nature of the area. The downtown is on the top of the hill from where the five ridges are branching off toward the Tiber River valley. On the contrary, the side slopes acted as natural limits for the human presence. In particular, the slopes orientated toward east and north-east show high slope angles, whereas the others facing west and south-west show more gentle values (Fig. 2). The difference in the morphology is due both to the depositional phase and to following tectonic displacements. The normal faults affecting the hills and the alluvial valley of the Tiber River (Fig. 1) created the necessary conditions for a generalized instability of the drainage network. All the rivers, mainly the ones flowing toward east and south-east, are very far from a graded longitudinal profile. For these reasons, they show intense erosion on the upper course and along the drainage divide. This morphological arrangement has heavily affected the urban development over the centuries, since the first meaningful anthropic settlement, due to the Etruscans (sixth and third centuries B.C.). The great Etruscan walls surrounding the core of the historic centre (Fig. 2) show a lobed trend with convex curves along the ridges and the concave segments corresponding to the drainage headwaters.

Even if in the medieval period the new city walls expanded (Fig. 2), they were still conditioned by the hill morphology that, in some sections, it obliged to retrace the older Etruscan ones. Inside these two defensive perimeters, the spatial disposition of the buildings and streets still follow today the topographic arrangement. Only after World War II, the urban building expanded along the eastern and south-eastern slopes of the hill (Fig. 3).

Just because the space inside the walls was limited and also because the fluvial-lacustrine deposits that make up the hill are easy to dig, the inhabitants found it convenient to create numerous cavities in the subsoil of the historic centre. Starting from the Etruscans and continuing until World War II, a large number of underground sites were produced. The oldest cavities are related to the Etruscan age with different uses as wells, tanks or tunnels for water consumption or, conversely, to drain excess water. Frequent use of anthropic cavities is also related to the burial of the dead. Numerous tombs and some large necropolises have been found over the years both near the top of the hill and at the base (Bizzarri et al. 2018; Melelli et al. 2019 and references within). In the medieval period, when Perugia City reached its economic and cultural peak, and from the fifth to the eighteenth century, other anthropic cavities have been made, mainly for drainage and for food 


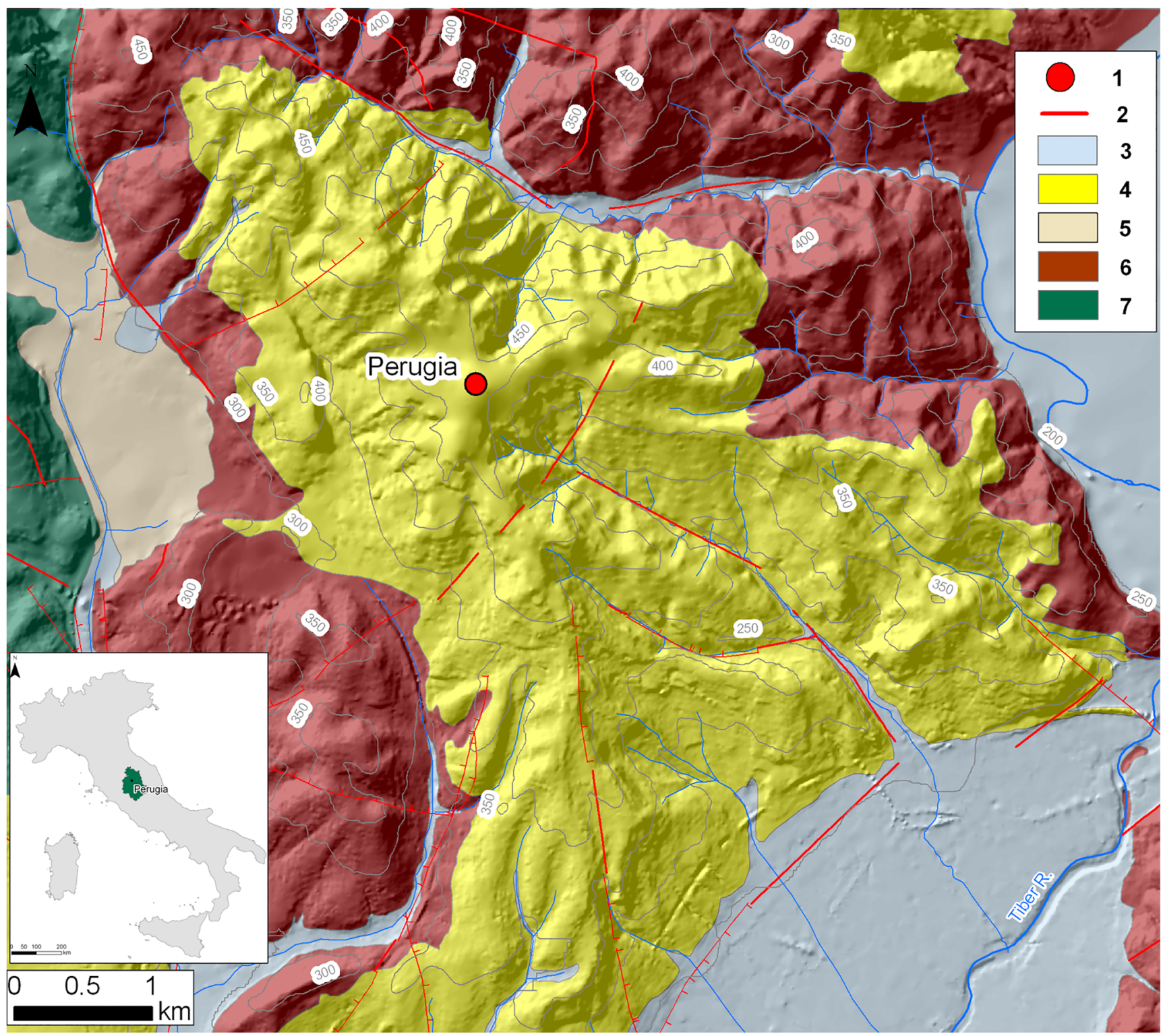

Fig. 1 Geological map of the Perugia City area with the location map of the Umbria region. 1, The Perugia downtown; 2, faults; 3, alluvial deposits (Holocene); 4, fluvial and lacustrine deposits (lower

Pleistocene); 5, lacustrine deposits (medium Pleistocene); 6, terrigenous complex (Burdigalian-Tortonian); 7, limestone complex (upper TriassicLower Miocene)

storage. For a long time, most of the spaces were abandoned and many of them forgotten. In the second half of the last century, speleological explorations and surveys committed by the municipality have made it possible to identify and map many of the historical tunnels in the city centre (Fig. 4).

The presence of these historical tunnels linked together with the numerous anthropic and geomorphological histories of the city, making Perugia a very suitable case study for urban geology and geomorphology.

Nowadays, a new research project named HUSH (Hiking in Urban Scientific Heritage) Underground, financed by the University of Perugia, is investigating the Perugia Underground with a multidisciplinary approach to combine and update previous knowledge in a single database.
Actually, about two hundred cavities have been registered, distributed in several parts of the hill according to the topographic settlement. Each anthropic and historical cavity has been geolocated in a geographic information system (GIS) and modelled as a vector point feature. A couple of $X, Y$ horizontal coordinates locate the entrance of the cavity on the topographic surface with an added $Z$ coordinate for the altitude value. Moreover, other topographic information completes the description of the position. The GIS environment allows the visualization of the Perugia Underground as a standalone territorial layer in a multidimensional approach of the city. In the related attribute table of the vector layer, different types of information have been stored. A quantitative description summarizes the geometric properties of the cavity 


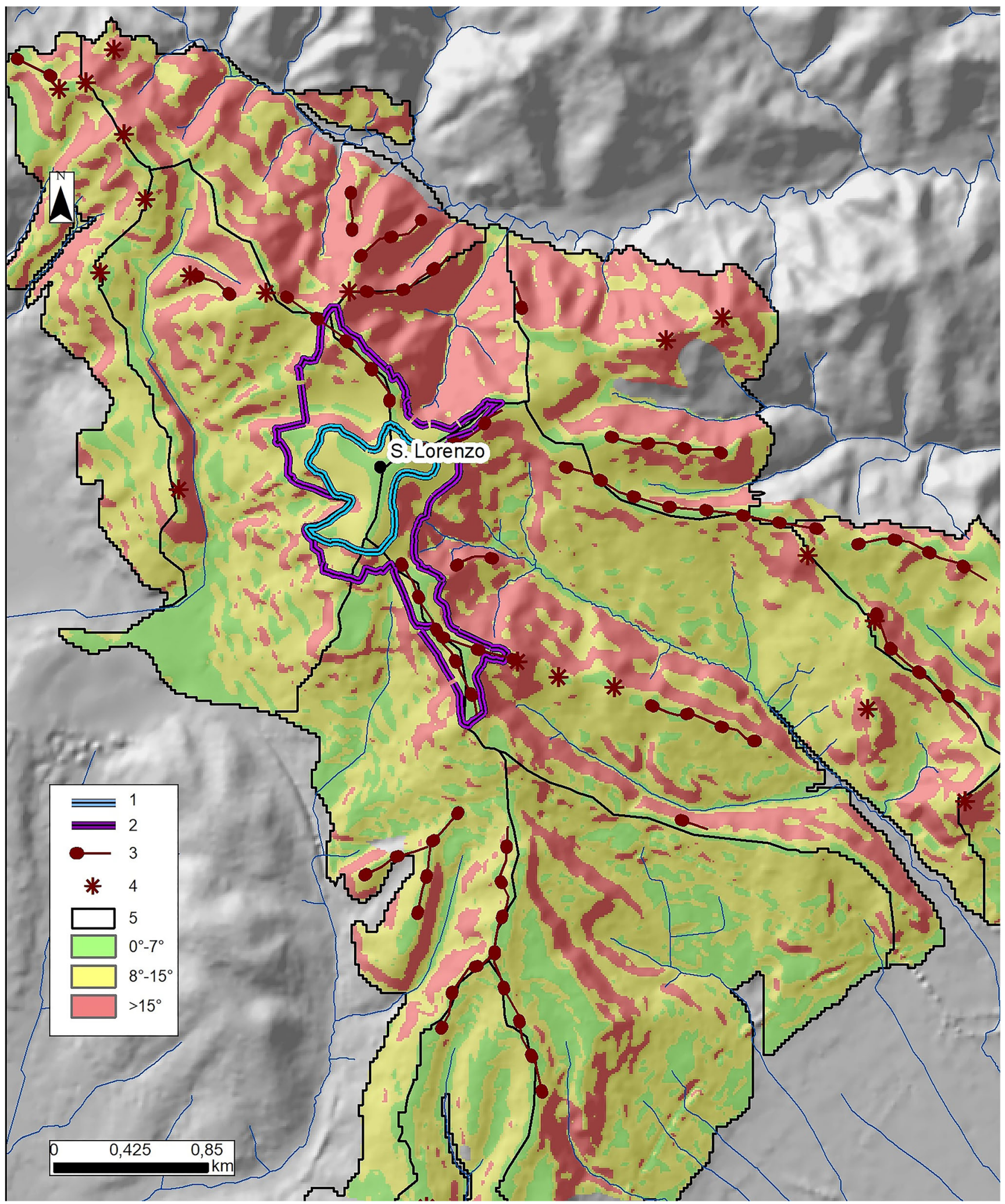

Fig. 2 Slope values on the fluvial and lacustrine deposits of the hill of Perugia. 1, Etruscan walls; 2, medieval walls; 3, ridges; 4, peaks; 5, drainage divides; 6 , slope values $0^{\circ}-7^{\circ} ; 7$, slope values $8^{\circ}-15^{\circ} ; 8$, slope values $>15^{\circ}$. The slope values cover the fluvial and lacustrine deposits

measuring the length, width, height and depth of underground level. The geological data, as grain size, attitude, thickness and sedimentological and hydrogeological interpretation, have been updated where access was allowed. Also, qualitative data 


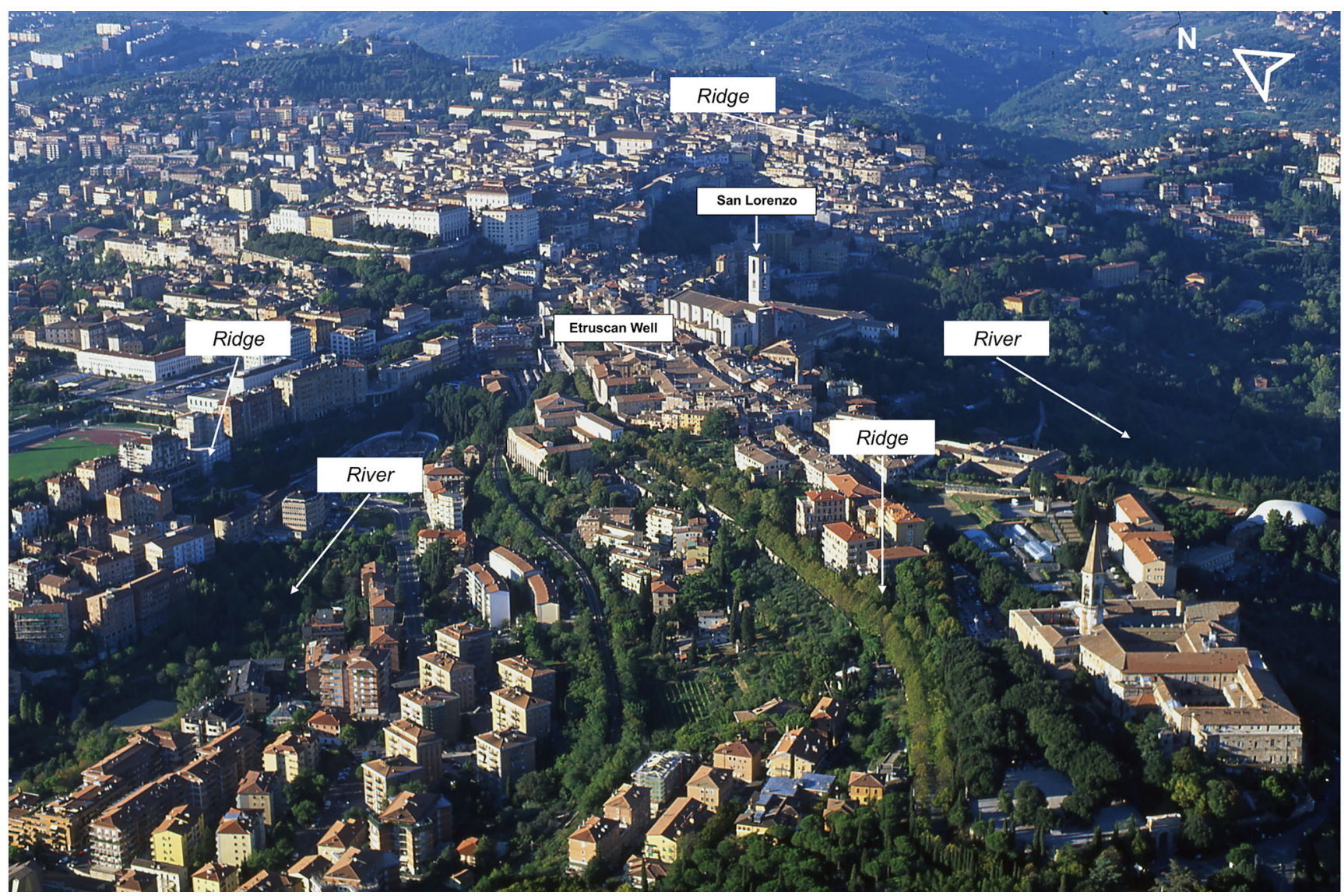

Fig. 3 Perugia City from above. The perspective highlights the spatial distribution of the houses in the downtown on the ridges and the natural divides in correspondence of the rivers

as the type of cavity, the building time period, the references and hyperlinks to external documents complete the site description. The project aims to obtain complete framing of the underground city for different purposes: to have a database of the geological information in urban areas, to update the map of the underground city and to support the geoheritage evaluation and promotion.

\section{The Underground Network Around the Etruscan Well}

The Etruscans funded the first settlement in the sixth century B.C. on the top of the hill, where, in the natural and initial arrangement, two reliefs (named Colle del Sole and Colle Landone, see Fig. 4) characterized the natural morphology. The two little hills were interspersed with a deep saddle, artificially filled since the medieval period. Along this direction, the roman street with an N-S direction (cardo) was present, where still today, the main road of the downtown (Corso Vannucci) is located. In the Piazza IV Novembre, several important sites were discovered, testifying that the public square (forum) was located here, where the cardo (N-S direction) crossed the decumano (E-W direction).
The choice of the strategic settlement was suggested by several characteristics: the highest position guaranteed the defence from external incursions and the unhealthy conditions of the valley areas. Moreover, the abundance of spring and groundwater ensured the water supply and the use for irrigation purposes. The Etruscan civilization found in Perugia a key place for its growth, and between the sixth and third centuries B.C., Perugia was fortified by great town walls, built with massive travertine blocks. Archaeometric studies based on the chemical composition of the major and trace elements allowed to determine the origin of these building materials in a quarry located close to Perugia (Petrelli et al. 2004). The Etruscan walls are interrupted and opened in seven doors, and inside this fortified perimeter, other relevant signs of the Etruscan civilization are present. Road sections, domus and floors, sometimes reused in Roman times, are under the actual pavement, and most of all wells and tanks are the key point of the historical and archaeological heritage of the downtown. In particular, the Etruscan Well, also interpreted as a tank, is probably the best expression of the hydraulic talent of the Etruscan people (Cenciaioli 1991, 2017; Stopponi 1991; https://www.pozzoetrusco.it/en/home-4/). The Well, dated to the second half of the third century B.C., is a cylinder with a 
Fig. 4 The downtown of Perugia with the location of the most important anthropic cavities. 1, The Etruscan Well and Piazza Piccinino location; 2, cavities; 3 , historical tunnels; 4, Etruscan Walls

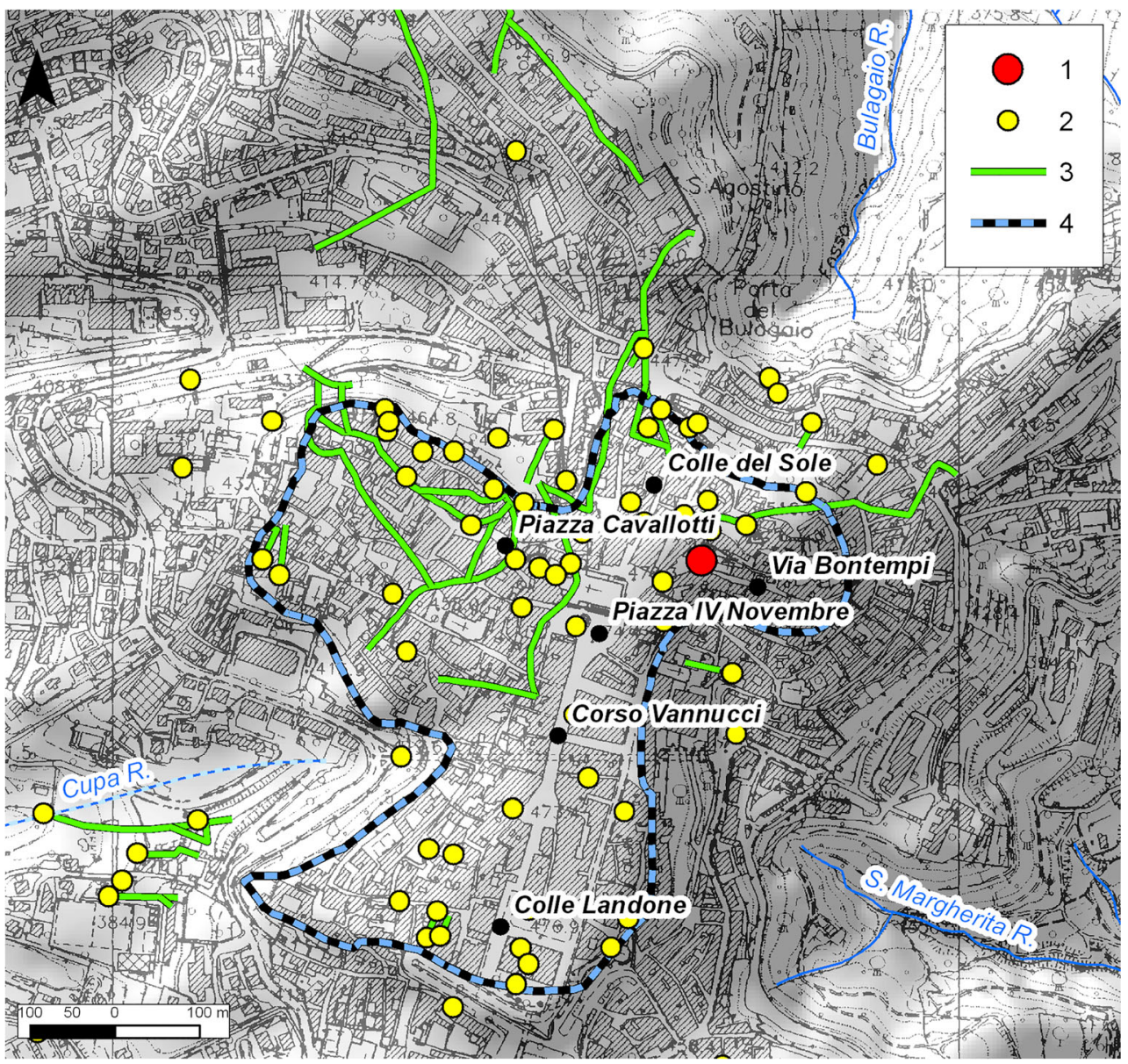

diameter of about $5.6 \mathrm{~m}$ from the topographic surface up to 12 $\mathrm{m}$ of depth (Fig. 5).

This first section is internally covered by large travertine blocks and, moving downward, the shaft narrows to only $3 \mathrm{~m}$ of diameter: totally, the Well reaches a depth of around $37 \mathrm{~m}$. The entire perimeter, except for the most superficial section is dug in the natural ground. In the central space between the beams, a square opening allowed the drawing of water, performing the function of water supply for the city of Perugia until the Late Middle Ages. On the square, the well is closed by an iron grate bearing the date " 1768 " and the coat of arms of two owners' noble family, named Bourbon di Sorbello and Eugeni. The Well shows an unusual size, if compared to other similar Etruscan water reservoirs. Due to this fact, it has been interpreted as a cistern only later converted into a well to intercept the aquifer. The Well is actually open to the public by a path where, after an entrance stair, the tourists cross the Well on a plexiglass footbridge that allows them to observe the perimeter walls and the covering made of travertine. Along the sides of the Well and most of the entrance stairs, the natural sedimentary deposits are visible. Sand and pebbles lens show a dip angle of around $41^{\circ}$ and a north direction of the palaeocurrent (Fig. 6).
Due to the excellent state of conservation of the deposits along the access walls and the different orientations, the Etruscan Well can be defined as an archaeo-geosite (Melelli et al. 2016; Bizzarri et al. 2018; Melelli 2019). These kinds of places are a unique opportunity to connect geology to archaeology and, in a broader sense, to highlight the geological component of the urban landscape to other cultural and tourist attractions. But, limiting the geological information to a single place could be a fruitless exercise where only some sedimentological and stratigraphic concepts can be transferred. On the other hand, starting from punctual and local information to broadening the interpretation of the surrounding areas can be much more interesting. Thus, the archaeo-geosite is the starting point for a storytelling of the history of the natural setting of the urban site, before the human presence.

The Etruscan Well in Perugia is located in a sort of "archeo-geological crossroad". Very close to the core of the Etruscan city and later to the roman forum, the Well had to be one of the poles of attraction of the city life for the water supply. Moreover, the area summarizes the lithological and hydrogeological conditions of the hill of Perugia. The hill (Colle del Sole) has shown, since ancient times, problems related to the slope stability due to the high values of slope 


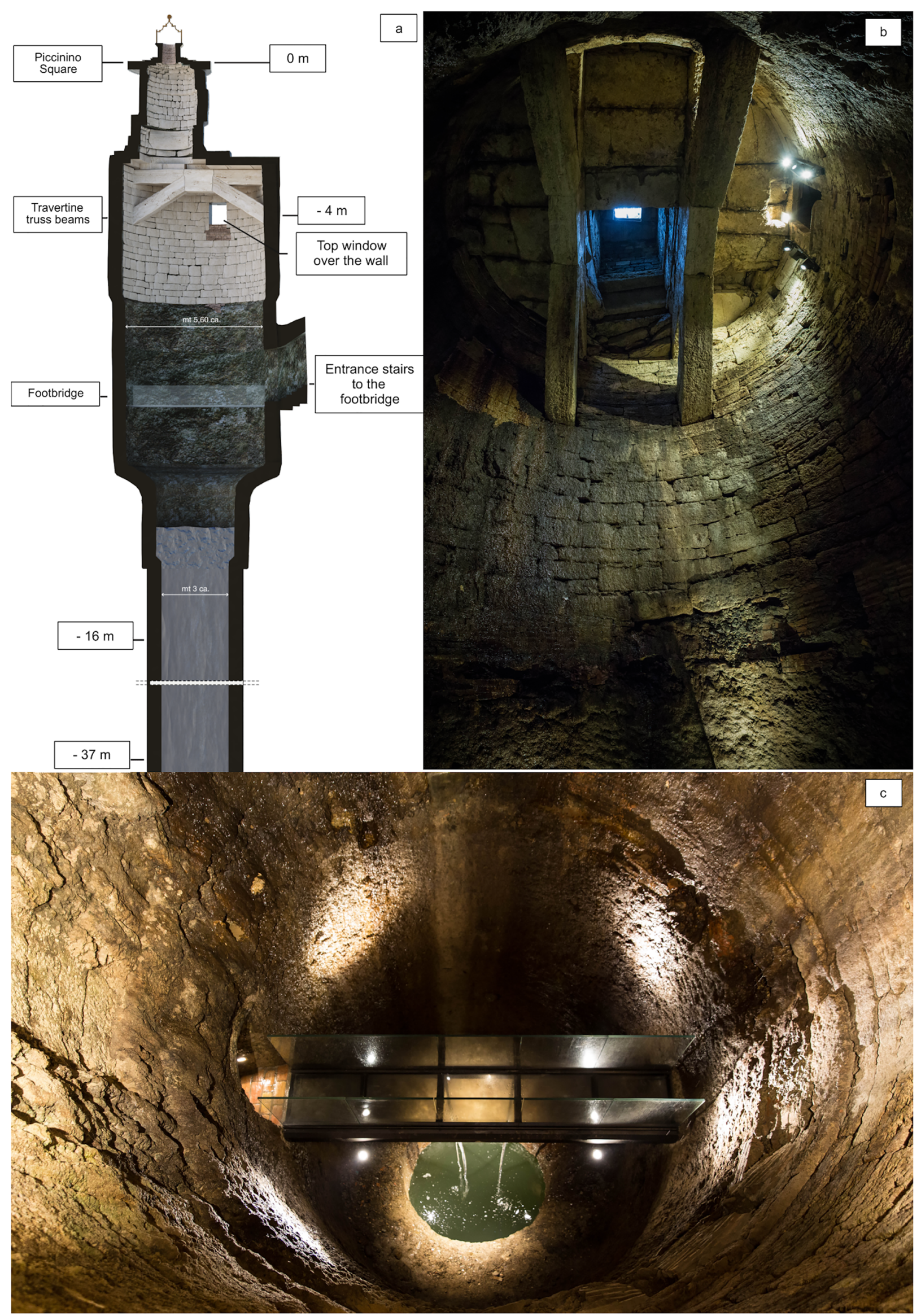


Fig. 5 The Etruscan Well. a Longitudinal section of the Well from the Piccinino square up to $-37 \mathrm{~m}$ of depth. $\mathbf{b}$ The travertine truss beams with the opening on the Piccinino square. $\mathbf{c}$ The footbridge crossing the Well with the entrance on the left. The photo is taken from the top window; see location in a (images modified from https://www.pozzoetrusco.it/)

angle, in particular toward north direction, as already shown in Fig. 3. Clear signs of substructure walls are visible under the San Lorenzo Cathedral (in Piazza IV Novembre) and in the Piccinino square where the Well is (Matracchi et al. 2019). The area, even if it is in the highest portion of the city, still has today numerous awash basements of the historic buildings. This condition can be interpreted as an ascent area of a remarkable artesian aquifer. For facilitating the drainage to the river network flowing northward, several drainage works were created over the centuries. The result is that the subsoil of Piccinino square is intersected by a multitemporal structures (tunnels but also pavement roads) not completely known and mapped. The square is one of the most trafficked of the downtown, crossed even by heavy vehicles. For this reason and the importance of the archaeological and historical site, it was deemed appropriate to investigate the presence and state of any tunnels.

Because of the high cultural value of the area, only noninvasive investigations are permitted, which are able to investigate the subsoil for the depth potentially affected by ancient anthropic evidence.

\section{Methods}

The research has aimed to obtain an accurate representation of the archaeological complex of the Etruscan Well and the surrounding area through the most innovative geomatic techniques (Matracchi et al. 2019; Radicioni et al. 2020).

In particular, in the previous investigations along the perimeter of the Well, an arched opening, closed with blocks of rock, had been identified in the section closest to the topographic surface. The shape and the position of the opening suggested the beginning of a passage that was not mapped in historical documents. Moreover, in the Piccinino square's area, other documents confirmed the presence of anthropic
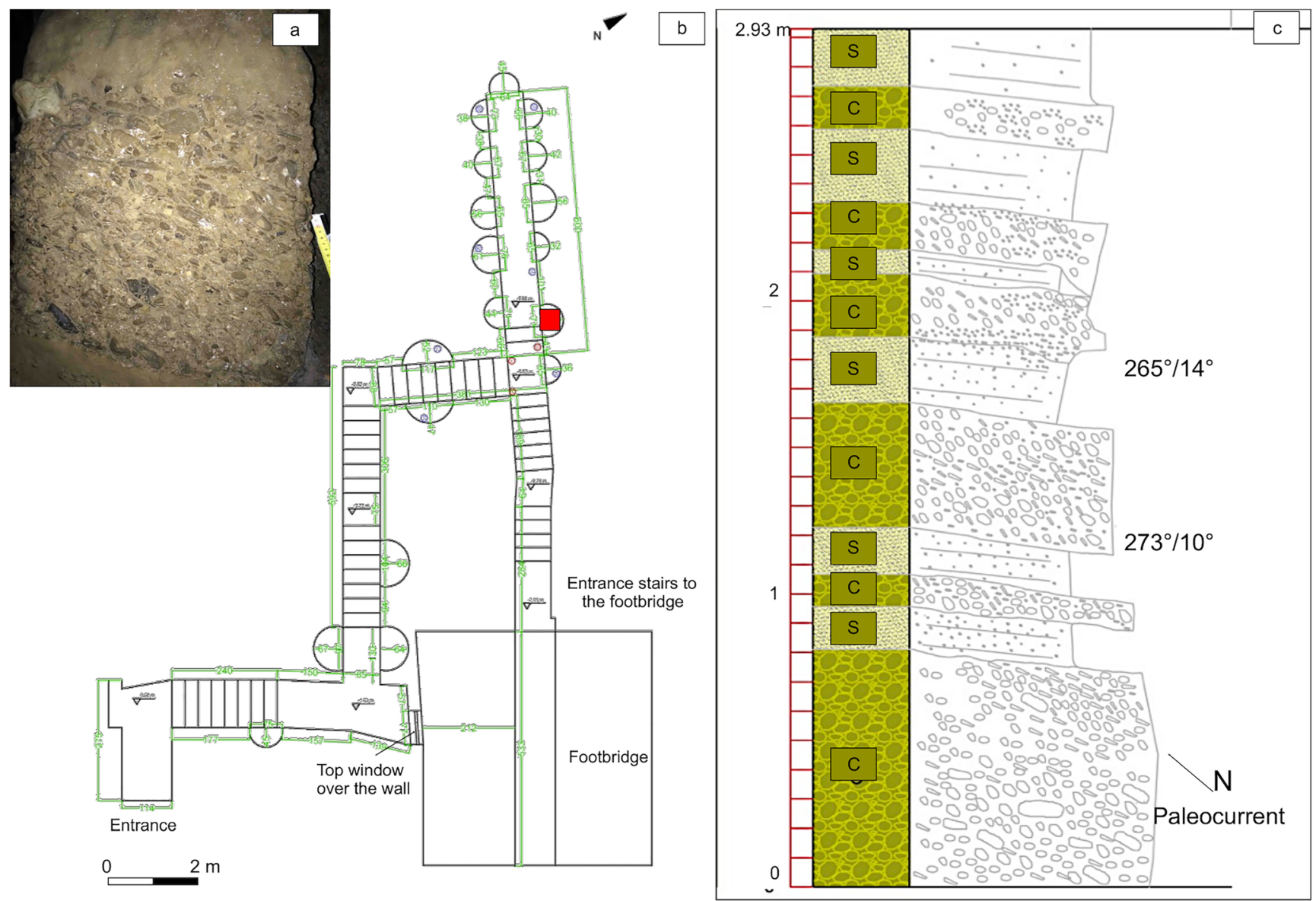

Fig. 6 The fluvial deposits outcropping along the entrance stairs to the Well. a A typical example of the fluvial deposits with a first level of conglomerates and a successive sandy event. b The map from the entrance to the Well. The red square is the location of the deposits in $\mathbf{a}$.

c The stratigraphic section of the point located with the red square in $\mathbf{b}$, with the rhythmic sequence of conglomerates (C) and sands (S) and the north direction of the palaeocurrent 
cavities (Melelli and Rosati 2019). For these reasons, an investigation of the subsurface arrangement is needed with noninvasive methods.

\section{Terrestrial Laser Scanning and Global Navigation Satellite System}

The terrestrial laser scanning (TLS) technique is a modern high-resolution geomatic survey system able to measure a significant number of $3 \mathrm{D}$ points performing a real $3 \mathrm{D}$ scan of the object (Brigante et al. 2009; Tucci and Bonora 2015). The output is a very dense set of points called "point cloud". The TLS survey allows to better investigate the entire zone in order to have a detailed 3D model useful for analysing and describing the geometry and the features of the scanned object. The Global Navigation Satellite System (GNSS) precision positioning technique allows to locate accurately geomatic surveys, obtaining a subcentimetre accuracy using geodetic receivers with multiconstellation and multifrequency signals (Teunissen and Montenbruck 2017). This technique is usually integrated with TLS survey in order to obtain a georeferenced 3D point cloud (Schuhmacher and Boehm 2005).

The use of TLS coupled with GNSS survey was carried out on November 19, 2018; 19 scans have been obtained to complete the 3D survey of the Etruscan Well and part of the Piccinino square, starting from the lower part of the cavity. Due to the underground nature of the Well, characterized by a rapid difference in height, narrow spaces and poor lighting, the scans were carried out at short distance, using some spotlight to light up the cavity. To align and georeference the model, a complex reference network has been set up around the area using GNSS satellite positioning and total station in a well-defined global datum (ETRF2000). The GNSS positioning was performed in relative positioning (static mode), obtaining a $<1-\mathrm{cm}$ position accuracy, using Topcon LEGACY GGD receivers and LEGANT antenna mounted on tripods over three points located in the near external areas. The receivers were kept in position for about $4 \mathrm{~h}$, acquiring GPS + GLONASS dual-frequency phase/code data with a 5-s epoch (Fig. 7).

A total station (Leica TS06) was used to connect the external GNSS points with an internal 3D reference network and to measure a large number of targets, consisting of black/white checkerboard pattern placed on the internal and external walls, necessary for the point cloud alignment. The resulting position accuracy on the targets was $<2 \mathrm{~cm}$.

\section{Ground Penetration Radar}

GPR is a non-destructive method able to provide subsurface images with a centimetric resolution. The technique is based on the reflection of radio waves: in geological and archaeological applications, the operating frequency range is generally comprised between 10 and $2000 \mathrm{MHz}$. The electromagnetic pulses are generated and received by transmitting and receiving antennas, and generally, the acquisition is triggered by an odometer wheel (Jol 2009). The EM waves are typically reflected and/or diffracted by interfaces separating media characterized by different physical properties when the dielectric contrast is sufficient to permit their detectability. In low-loss media (Daniels 2004), these variations are generally due to subsurface geolithological changes (Bristow and Jol 2003) and/or soil moisture variations (Ercoli et al. 2018 and references therein). The GPR penetration is inversely controlled by the electrical conductivity of the soil; therefore, high values of this physical parameter generally produce high GPR signal attenuation (Davis and Annan 1989; Annan 2001). The reflected pulses are recorded as a function of the traveltime propagation in a GPR trace (or A-scan). The collection and visualization of several GPR traces along a transect constitute a radargram (B-scan), representing the standard output of a GPR prospection. Recently, the wider diffusion of GPR instruments equipped with antennae array allows the operators to generate GPR tridimensional volumes (C-scan), extremely useful in archaeological applications (Campana and Piro 2008; Goodman and Piro 2013; Conyers 2016; Deiana et al. 2018) especially in extensive 3D surveys for the possibility to generate time slices (Leckebusch 2003; Trinks et al. 2018). GPR is often used in archaeological application in combination with other geophysical methods (Capizzi et al. 2012; Pueyo-Anchuela et al. 2016; Agapiou et al. 2017; Bottari et al. 2017; Casas et al. 2018; Yilmaz et al. 2018; Grassi et al. 2019; Martorana and Capizzi 2020). Traditional GPR prospecting aiming to image ancient villas remains, and foundations have been carried out over the last 20 years (Pipan et al. 1999; Booth et al. 2008; Novo et al. 2014; Wunderlich et al. 2015; Verdonck 2016; Piro et al. 2017; Ribolini et al. 2017; Gaballah et al. 2018; Imposa et al. 2018; Zhao et al. 2018; Orlando et al. 2019; Sala et al. 2020). Several papers report archaeological GPR surveys carried out for the detection of crypts, galleries and tunnels (Perez-Gracia et al. 2000; Lorenzo et al. 2002; Martinaud et al. 2004; Leucci 2006; Ramirez-Blanco et al. 2008; Novo et al. 2010; Ercoli et al. 2012; Orlando 2013; Núñez-Nieto et al. 2014; Morris et al. 2019; Diamanti and Annan 2019).

\section{Results}

Etruscan Well TLS survey was performed with a CAM2 FARO Focus 3D X130 instrument; this laser scanner is a small size, very light and extremely fast, and able to measure a great number of points in short times (up to one million points per second, Fig. 8). Thanks to the integrated 70 - 
Fig. 7 GNSS positioning receiver beside the Etruscan Well in the Piccinino square

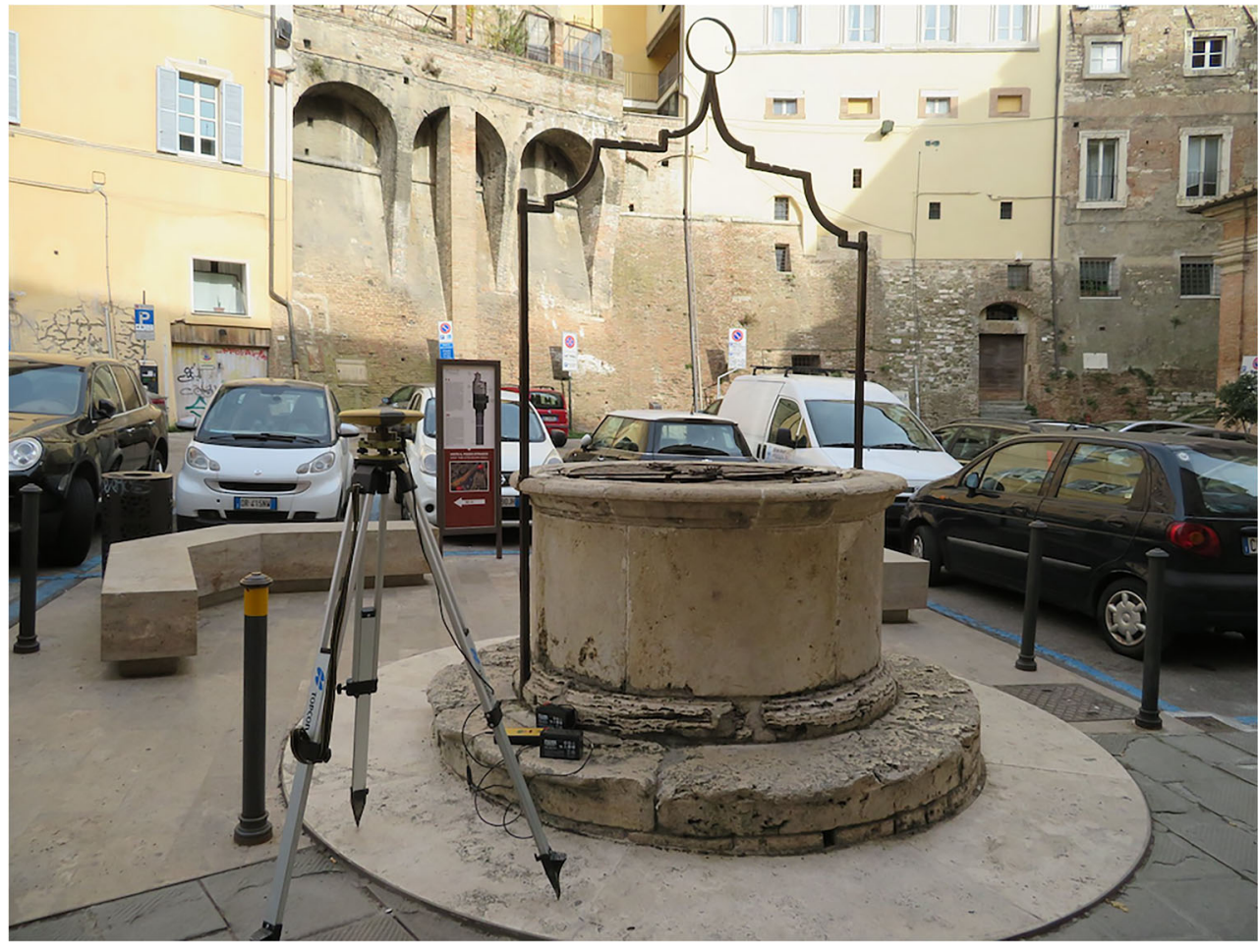

megapixel camera with automatic colour cloud overlap, it is possible to obtain an RGB point cloud.

The scans were carried out with an average resolution of about $7 \mathrm{~mm}$ at $10 \mathrm{~m}$ distance and an acquisition time of $8 \mathrm{~min}$ for each scan, obtaining an overall point cloud of about 500 million points. For correctly describing the geometry, it is necessary to scan the object from multiple points of view in order to have overlapping areas. Each scan corresponds to a point cloud, which is oriented in a local reference system coinciding with the instrumental reference system. As a way to obtain a unique point cloud, the single point clouds must be oriented to each other (relative orientation) through a $3 \mathrm{D}$ roto-translation maintaining a fixed reference cloud. For the alignment, a minimum of 4 common points between adjacent scans (called target) is necessary. Targets consist of square plates with black/white checkerboard pattern. During the scan process, a set of 6 reference spheres was used for the relative orientation in addition to checkerboard targets. The use of the reference spheres in this kind of survey is heartily recommended since the scanner software automatically detects them and accurately determines their centre coordinates from each scanner position, reducing the relative alignment error of the point clouds. In this case, it was also necessary to use some reference objects present in the scan area, especially planes and pipes, for reducing the registration error.

Fig. 8 CAM2 FARO Focus 3D $\mathrm{X} 130$ laser scanner during the Etruscan Well survey

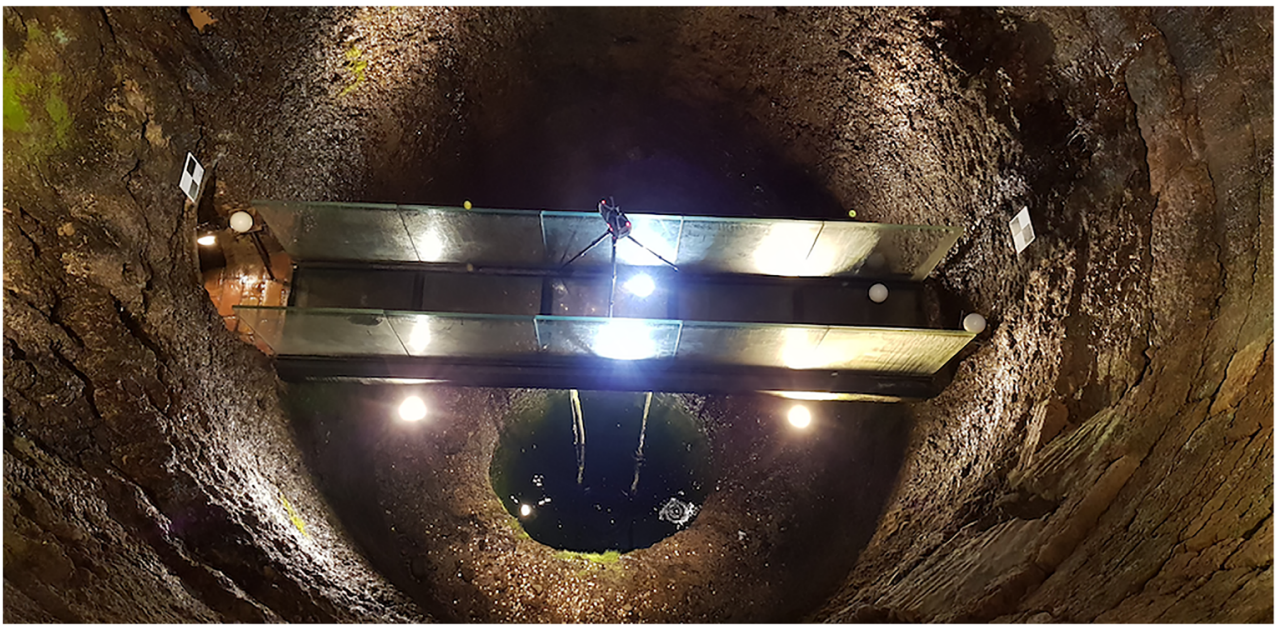


CAM2 SCENE software was used to align the scans, performing a spatial roto-translation of the single clouds; the final solution was a single point cloud oriented in a local reference system that corresponds to the reference one. The parameter that identifies the registration accuracy is the "normalized tension": the obtained value can be considered largely admissible, and it is about $1.9 \mathrm{~mm}$ (Fig. 9). The overall georeferencing procedure in the ETRF2000 datum was carried out through the Leica Cyclone software v. 9.2.1. The procedure corresponds to a roto-translation of the overall point cloud with respect to the $3 \mathrm{D}$ target coordinates in the assigned datum, determined by the reference network.

This automatic process identifies the constraints existing between point cloud and target network, through an evaluation procedure that finds the differences, in terms of distance, between these points. The mean RMS value is about $8 \mathrm{~mm}$. Before generating the final products, a filtering method has been applied to reduce the point cloud noise. With this instrument, it is possible to obtain a 3D visualization of the entire artefact and understand its position in space.
Fig. 9 Final point cloud of the Etruscan Well and surrounding area, resulting from the assembly of the single scans. In $\mathbf{a}$ and $\mathbf{b}$, the red square is the location of the top of the Well, viewed from different angles
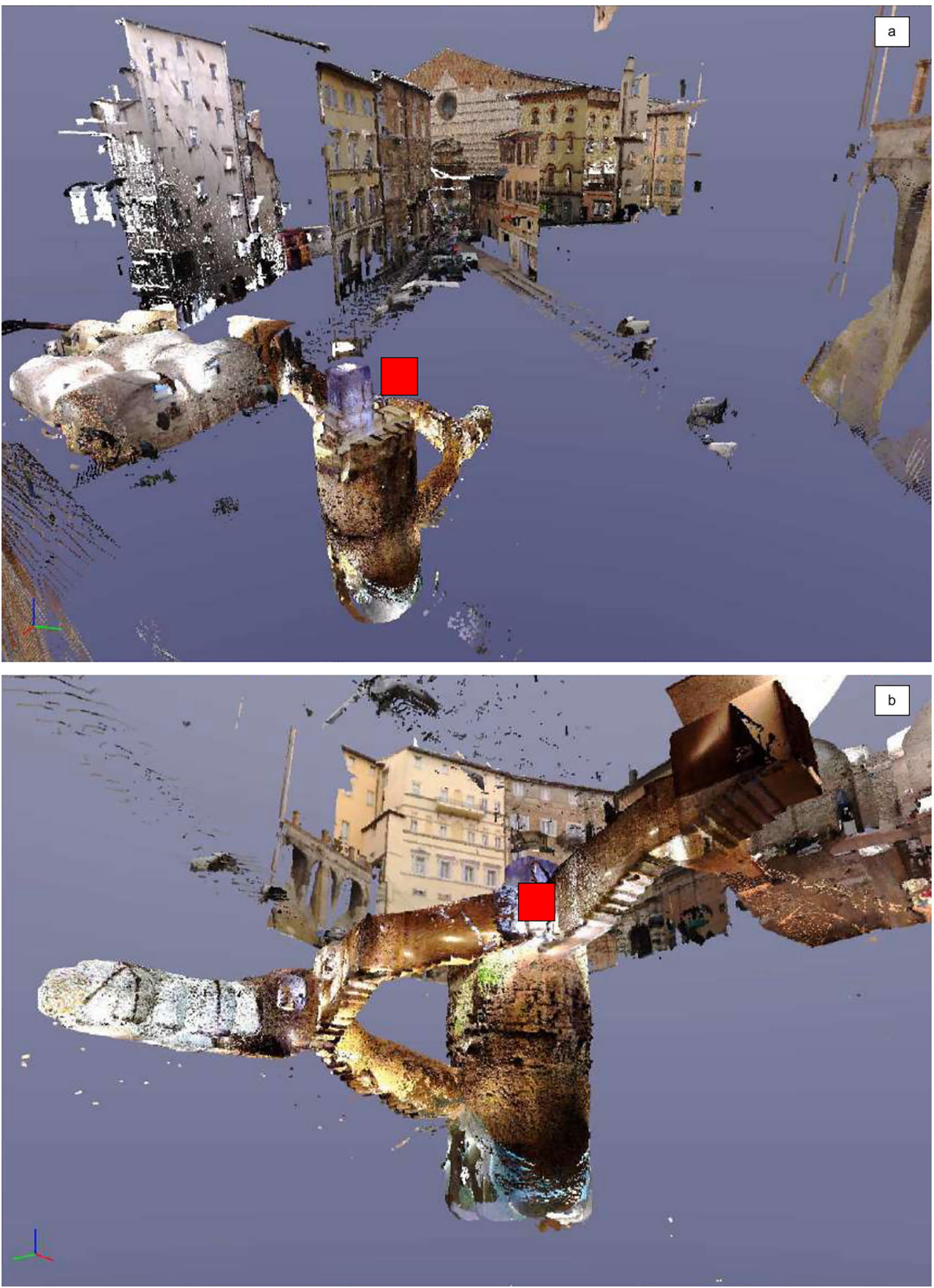
To integrate the LS data, a 2D GPR was carried out in the Piccinino square (Fig. 10) to detect buried anomalies beneath the study area. We used RadSys Zond-12e Advanced (http:// www.radsys.lv/en/index/Latvia) equipment with a $500-\mathrm{MHz}$ antenna to theoretically achieve a metric signal penetration maintaining at the same time high resolution of radargrams (Annan 2001). The latter would be allowing the detection and discretization of shallow diffractions (e.g. network of utilities) from reflected events or interferences of reflections/ diffractions originated by bigger cavities. In fact, as typically happen in historical urban centre, a dense distribution of pipes, wires and welded meshes in the shallow subsurface may potentially generate echoes hampering the detection of deeper targets. A grid of 2D GPR lines crossing the western sector of the square was designed in order to test the GPR efficiency in terms of penetration and resolution limits and verify the presence of possible unknown voids (Fig. 10). The GPR profiles were collected in N-S directions and were laterally spaced 10 $\mathrm{m}$, whilst other three radargrams $(5 \mathrm{~m}$ spaced) were collected in NE-SW direction. We have positioned the GPR profile's start and end points through metric strings, triangulating the distances from some reference points at the surface (e.g. buildings corner and other infrastructures). We have also used an odometer wheel connected to the antenna to trigger the acquisition and measure the distance between each GPR trace. The lines have variable length due to surface obstacles within the survey area and due to the buildings surrounding the square.

The acquisition parameters of the SEG-Y data collected are summarized in Table 1. The data acquisition and processing were performed with Prism software (RadSys). We have used a conventional flow (Jol 2009) including amplitude recovery function, bandpass filter and background removal filter to eliminate low- and high-frequency noise components and horizontal ringing (processing parameters summarized in
Table 2). The time-to-depth conversion was done after using an average EM wave velocity of $11.7 \mathrm{~m} / \mathrm{ns}\left(\varepsilon_{\mathrm{r}}=6.5\right)$, obtained after a velocity analysis (diffraction hyperbola fitting, e.g. Ercoli et al. 2013).

The processed data allow us to visualize several GPR anomalies in the subsurface of the square, including many diffractions at shallow depth and several deeper highamplitude reflectors characterized by good lateral continuity. Figure 11 provides a clear image (profile 2L in Fig. 10) representative of the main GPR anomalies, with polygons of different colours above the targets drawn to aid the interpretation. A subhorizontal reflector within the first $0.50-0.6 \mathrm{~m}$ of depth (green dashed line) depicts the shallower subsurface, including the pavement and its base layer, which include small diffractions (yellow circles). Under this level, the radargram displays wide hyperbolic anomalies (red circles). Their signature, characterized by strong amplitudes, suggests, in most cases, the presence of voids of metric-submetric width. The depth of such anomalies is included in the range $0.5-2.5 \mathrm{~m}$, and even if the top generally corresponds to the shallower strong diffraction, the identification of the base is more complex due to the numerous reverberations typical of air-filled voids. More accurate and complete identification of the targets across the Piccinino square would require extensive and denser GPR profiling, particularly to delineate their spatial extent and orientation, which, in some cases (e.g. blue box), might not be perpendicular to the actual profile's direction.

\section{Discussion}

The non-invasive techniques employed in this study showed strong complementarity of the resulting data.
Fig. 10 Location map of the 2D GPR profiles collected in the Piccinino square. The green lines are the N-S lines (L series), whilst in pink colour ( $\mathrm{T}$ series), the NESW ones

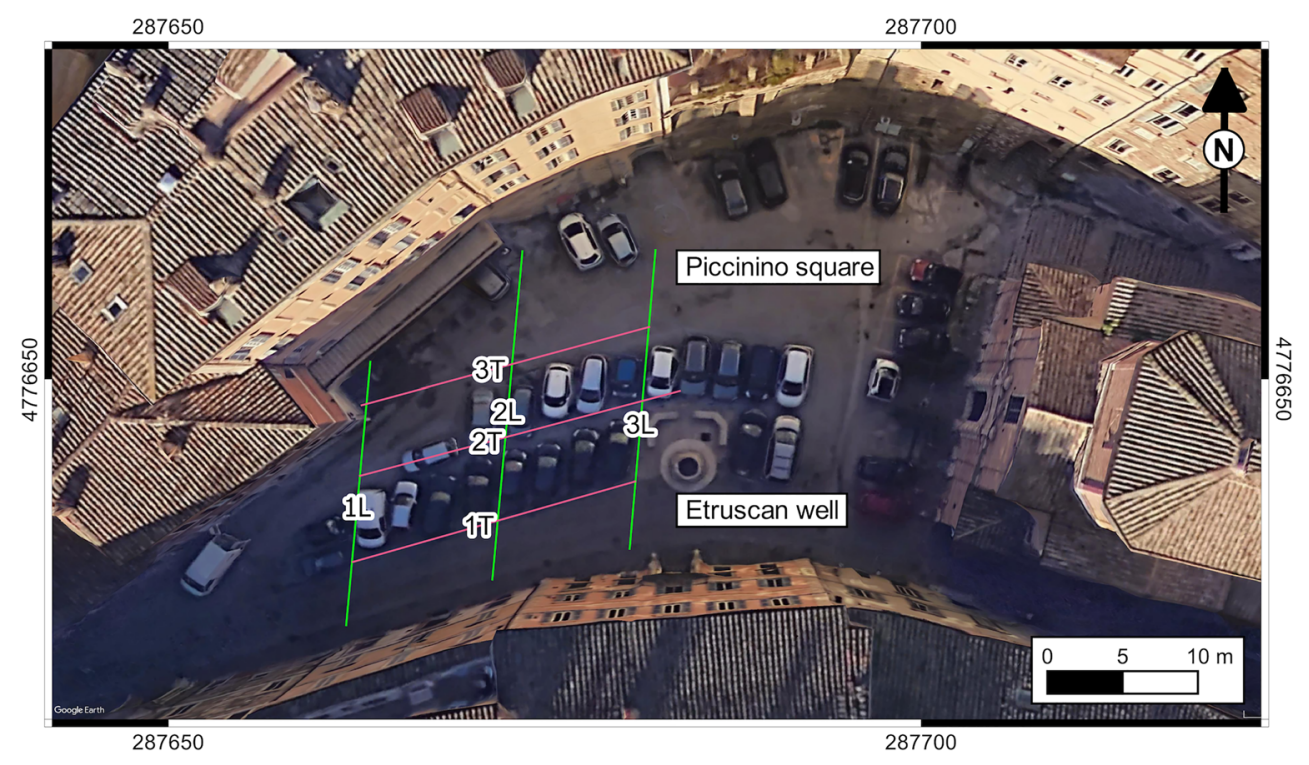


Table 1 Acquisition parameters used during the GPR surveying

\begin{tabular}{llllll}
\hline $\begin{array}{l}\text { Profiles/ } \\
\text { parameters }\end{array}$ & $\begin{array}{l}\text { Profile length } \\
(\mathrm{m})\end{array}$ & $\begin{array}{l}\text { Time window } \\
(\mathrm{ns})\end{array}$ & $\begin{array}{l}\text { Samples/trace } \\
\left(\mathrm{n}^{\circ}\right)\end{array}$ & $\begin{array}{l}\text { Trace distance } \\
(\mathrm{m})\end{array}$ & $\begin{array}{l}\text { Sampling time } \\
(\mathrm{ns})\end{array}$ \\
\hline $1 \mathrm{~L}$ & 17.65 & 100 & 1024 & 0.02 & 0.098 \\
$2 \mathrm{~L}$ & 22.00 & 100 & 1024 & 0.02 & 0.098 \\
$3 \mathrm{~L}$ & 20.00 & 100 & 1024 & 0.02 & 0.098 \\
$1 \mathrm{~T}$ & 22.00 & 100 & 1024 & 0.02 & 0.098 \\
$2 \mathrm{~T}$ & 19.50 & 100 & 1024 & 0.02 & 0.098 \\
$3 \mathrm{~T}$ & 19.80 & 100 & 1024 & 0.02 & 0.098 \\
\hline
\end{tabular}

The TLS has provided an accurate 3D model of the well and access routes; moreover, the improvements in the rendering phase have reached an optimal viewing level. The overall model of the Etruscan Well, obtained integrating of different geomatic techniques, is characterized by an extended and articulated development of the underground spaces both horizontally and vertically. Three-dimensional continuous surface models with triangular meshes (TIN) have been acquired, allowing a more realistic and homogeneous visualization of details. These models have been currently used to create virtual tours, contributing to increasing the site museum visit experience. The $3 \mathrm{D}$ point cloud could provide metrical data information, and a series of detailed CAD drawings (plans, sections, internal elevations) has been obtained, useful for providing quantitative mapping and stability analysis (Ercoli et al. 2016) and for further geological or archaeological studies. In detail, the 3D point cloud allows to extract geomorphological and stratigraphic properties of the deposits with a great accuracy and reliability, for analysis and mapping purposes. This aspect could be very useful where the access is forbidden. The TLS revealed a complex network of underground spaces surrounding the Etruscan Well, allowing also to access other underground spaces that might develop in different directions beneath the square. This aspect could be very useful where the access is forbidden. Following this consideration, the GPR survey was used to extend the investigation across the study area, actually bringing to light the presence of numerous underground structures.

Table 2 Customized flow and a detail of the parameters used during the GPR processing

\begin{tabular}{ll}
\hline Processing flow & Parameters \\
\hline Amplitude recovery & Manual (customized curve) \\
Bandpass filter & Cutoff frequencies: $100 / 250 / 750 / 1000 \mathrm{MHz}$ \\
Background removal & Time window: $3-100 \mathrm{~ns}$ \\
Spatial filter (smoothing) & 3 traces \\
Velocity analysis & Hyperbolic fitting \\
Time-depth conversion & $V_{\mathrm{em}}=11.7 \mathrm{~m} / \mathrm{ns}\left(\varepsilon_{\mathrm{r}}=6.5\right)$ \\
\hline
\end{tabular}

In Fig. 10, a meaningful radargram summarizes the information derived by the GPR survey for the study area. Moving in depth from the topographic surface, the first level of anomalies (yellow circles) marks the utilities, possibly including pipes and wires of the electricity, water and sewerage network. The bibliographic research confirmed the location of these networks by some photos which portrayed the road paving works carried out in 1988, before being covered with porphyry briquettes. This group of anomalies is delimited to the bottom by a subhorizontal discontinuity (green dotted line), likely representing the bottom surface of the excavated ground.

A wavy interface between 0.7 and $0.9 \mathrm{~m}$ depth (blue box), characterized by adjacent interfering diffractions, could reveal the layout of an ancient paved Roman road. Segments of this road were found under the Cathedral of San Lorenzo (where they are still visible today), below the Cavallotti square and proceeding eastwards along Bontempi Street (see Fig. 3 for the position). By reconstructing the layout of the road, it is plausible that traces of this pavement are present underneath the actual main road on the southern side of Piccinino square in the position highlighted by the GPR.

Finally, the most relevant structures detected are the deepest ones, consisting of large diffractions above the aforementioned strong reverberations (red circles in Fig. 10). This is comparable with air-filled voids interpretable as tunnels or rooms as supposed by previous archaeological studies (Stopponi 1991). The amount of GPR anomalies detected suggests the possible presence of an additional complex network of cavities, currently unknown, potentially connected with the Etruscan Well.

Due to the abundance of groundwater rising, which still today give widespread problems of flooding of the basement of some houses and to the evidence of this phenomenon in the Etruscan Well too, the most probable interpretation is the presence of at least one underground water drainage tunnel. This tunnel could have been done to convey excess water toward the lower area near the Etruscan Arch (where other vertical and historical drainage wells are present) and the underlying basin of the Bulagaio River.

The GPR survey has therefore provided promising results, demonstrating the excellent performance and potential of the 


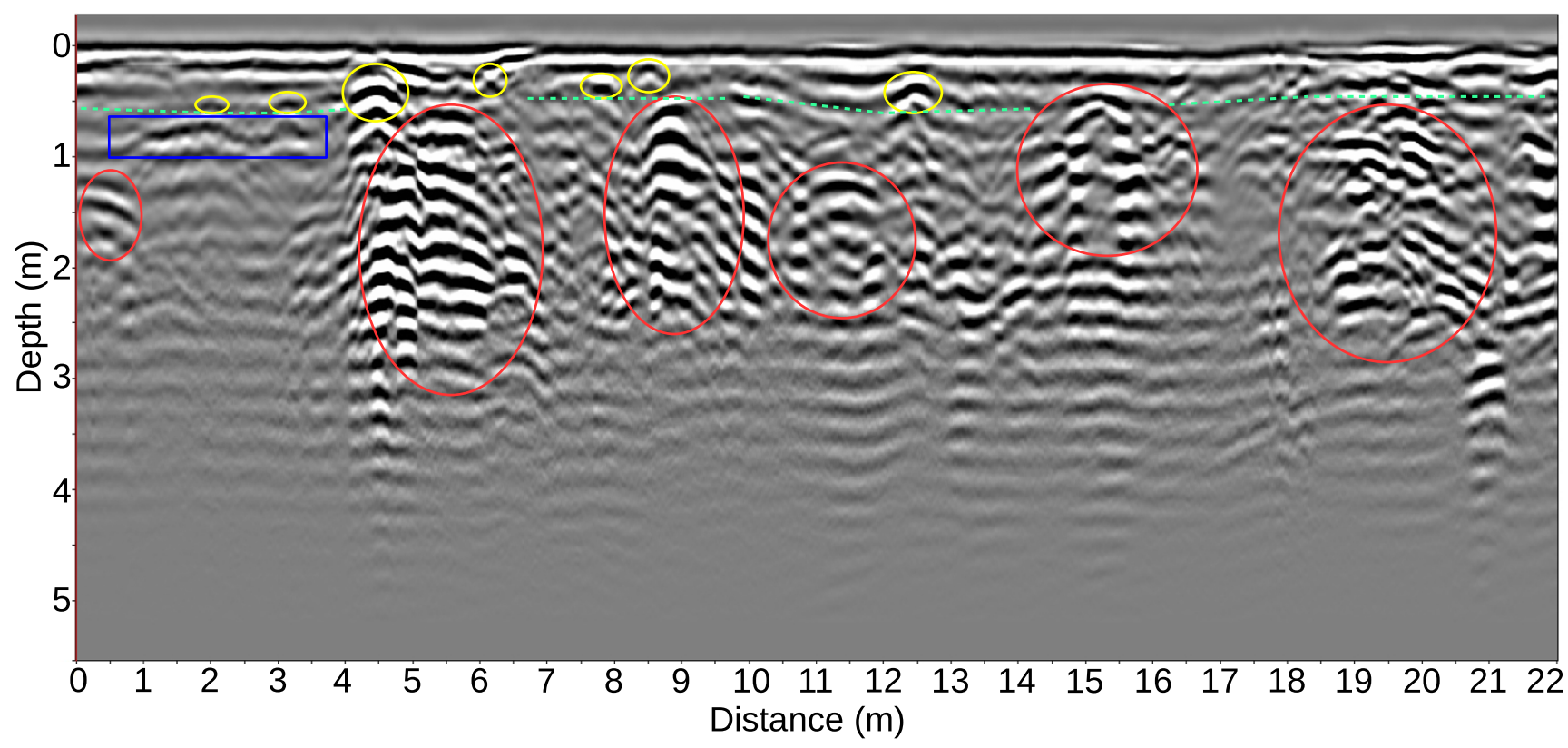

Fig. 11 GPR results of radargram 2L collected during the survey at the Piccinino square. The profile displays several high-amplitude anomalies suggesting the presence of numerous unknown air-filled voids in the subsurface. See the text for the symbols legend

GPR in identifying underground voids in urban environment. The instrument guaranteed high-resolution images, showing buried targets of different sizes and, at the same time, a metric range of penetration depth (about $2.5 \mathrm{~m}$ ); however, in some areas, there are numerous interfering echoes which increase the complexity and uncertainties of a 2D survey.

\section{Conclusion}

Two-thirds of the global population will live in the city by 2050. Urban areas are a crucial challenge for human health, and a high level of sustainability is mandatory. However, it is well evident that to achieve this aim, citizens and visitors should share the city in its complexity. Urban areas are not only "places" where human people live, work and have fun, but a multifaceted space made of territory and history. Cities should be better known and lived in their four dimensions: the two dimensions defining our position in the topographical surface, a third dimension from the topographical surface upwards where the buildings develop and the last one toward the depths of the subsoil. In this direction, the geological reasons of cities' location reveal the early natural context which initially influenced the choice of location and then the subsequent expansions of the urban building over the centuries. The actual urban landscape that we often live without being aware of is a delicate balance between structural factors, modelling agents, climatic conditions and human presence. Each territorial planning that is intended to be implemented to improve living conditions in the cities should take into account the natural context. This approach is fundamental to limit or avoid natural risks affecting urban areas such as flooding, landslide, subsidence and seismic or volcanic events. However, research is going toward a new perspective, considering the cities a resource for the geoheritage and, inside our daily places, a unique opportunity to discover the abiotic component of the territory. Some objective difficulties are evident. The urbanization over time masks or erases the natural background, in particular in the downtown where the historical changes are often more numerous and severe and where the natural soil do not emerge at all.

For this reason, the hypogean artificial cavities, when they are not covered along the perimeter walls, are the perfect place providing the opportunity to touch, view and understand the "geological reason" for urbanization, including the initial settlement choice.

One of the best opportunities for enjoying the cities' underground is linked to the geoarchaeological values that could be translated in the geotouristic activities, as guided visits, urban trekking and didactic or public events that find in the underground spaces a perfect frame (Asrat and Zwoliński 2012; Premangshu and Rahul 2019). Geotourism is a key to get geology out of the academic sphere and make it become a cultural theme usable by all, on a par with archaeology, architecture and history.

This paper describes a multidisciplinary approach for the investigation, enhancement and promotion of archaeogeosites in urban areas, assuming such places as sites where only non-invasive techniques may be employed. The study case, an Etruscan Well dated to the second half of the third century B.C., located in the heart of the historic centre of Perugia City and one of the most relevant Etruscan artefacts 


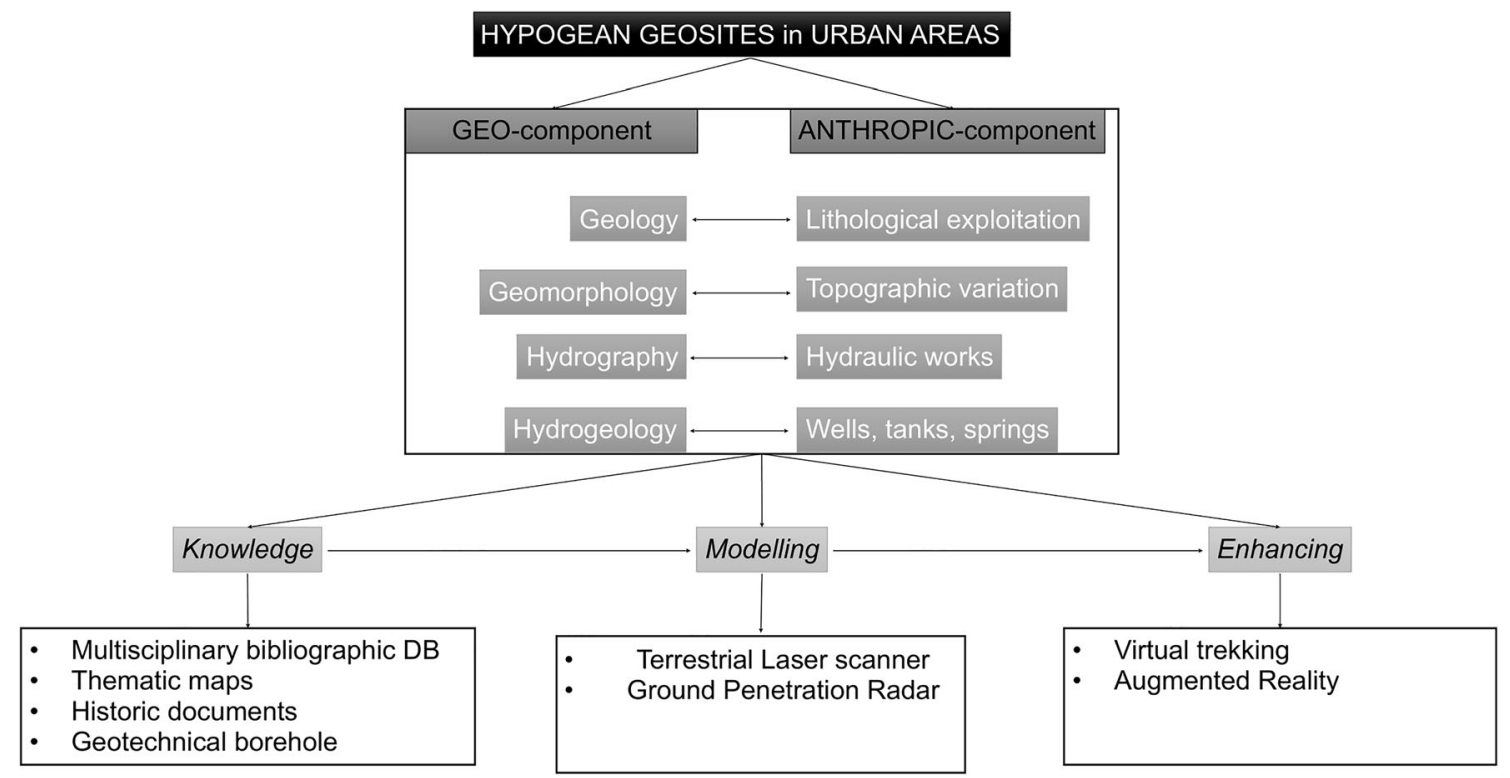

Fig. 12 Flow chart summarizing the steps required in a multidisciplinary approach for the investigation of the hypogean geosites in urban areas

in Central Italy, is a meaningful example of archaeo-geosite. Located under the actual road pavement and situated in the core of the Etruscan and later Roman city, it is surrounded by other ancient artefacts, not all known and mapped. The access road to the Well is also dug into the bedrock, and several stratigraphic sequences of the fluvial and lacustrine deposits which make up the hill of Perugia are recognizable. The Well is already one of the touristic attractions in the downtown, but exploiting the geological component could bring an added value to the touristic tours. The examination of the sedimentary deposits is the starting step for a storytelling of the geological and geomorphological arrangement of the area and a perfect link to understand the reasons of the human presence on the hill.

To complete the reconstruction of the surrounding area, non-invasive methods have been required. Groundpenetrating radar (GPR) surveys revealed other artefacts around the Well, such as buried tunnels or possible fragments of ancient roads. Moreover, the 3D model resulting from terrestrial laser scanner (TLS) is an incisive output for the visualization of the underground spaces.

Clearly, a further 2.5 or 3D GPR investigation would be highly desirable to shed light on the spatial relationships between the shallow utilities, the cavities and tunnels. Moreover, additional GPR investigations using lower-frequency antennas (e.g. $100 \mathrm{MHz}$ or $300 \mathrm{MHz}$ ) might be useful to extend the investigation range and focus the study on the bigger and deeper targets.

In Fig. 12, a comparison between the geological component and the anthropic ones in the investigation of the hypogean geosites in urban area is proposed.

For each natural geological factor, the corresponding anthropic component is suggested: the geological substratum is explored by considering the lithological exploitation. The geomorphological arrangement is relevant for the reconstruction of the topographic variation in time and space. The hydrographical and hydrogeological resources are at the base of the hydraulic works on the city and the presence of wells, tanks and springs. The geocomponent and the anthropic component should be both taken into account for the knowledge, modelling and enhancement of the geosites (Del Monte et al. 2013; Pica et al. 2016). This approach is the best solution to allow urban geology to become an economic resource for the enhancement of the geological heritage in the city. The digital data as images, movies and 3D reconstruction of the sites, are at the base of virtual tours both on websites and on site for the promotion of the underground heritage. The integration of these sites with the traditional and well-consolidated touristic attractors offers a new perspective for the fruition of the urban spaces with virtual and real trekking in the cities.

Acknowledgements We thank the Ranieri di Sorbello Foundation (http:// www.fondazioneranieri.org/) for involving us in this research and for having guaranteed us access to the Etruscan Well during the entire period in which the research took place. We also thank Prof. Simonetta Stopponi who provided insight and expertise that assisted the research.

Funding Open Access funding provided by Università degli Studi di Perugia within the CRUI-CARE Agreement. This research was funded by the University of Perugia, Department of Physics and Geology, project title "HUSH (Hiking in Urban Scientific Heritage) UNDERGROUND", RicBAs2018, awarded to Laura Melelli.

Open Access This article is licensed under a Creative Commons Attribution 4.0 International License, which permits use, sharing, adaptation, distribution and reproduction in any medium or format, as long as you give appropriate credit to the original author(s) and the source, provide a link to the Creative Commons licence, and indicate if changes were made. The images or other third party material in this article are included 
in the article's Creative Commons licence, unless indicated otherwise in a credit line to the material. If material is not included in the article's Creative Commons licence and your intended use is not permitted by statutory regulation or exceeds the permitted use, you will need to obtain permission directly from the copyright holder. To view a copy of this licence, visit http://creativecommons.org/licenses/by/4.0/.

\section{References}

Agapiou A, Lysandrou V, Sarris A, Papadopoulos N, Hadjimitsis DG (2017) Fusion of satellite multispectral images based on groundpenetrating radar (GPR) data for the investigation of buried concealed archaeological remains. Geosciences 7:40. https://doi. org $/ 10.3390 /$ geosciences 7020040

Alsharahi G, Faize A, Louzazni M, Mostapha AMM, Bayjja M, Driouach A (2019) Detection of cavities and fragile areas by numerical methods and GPR application. J Appl Geophys 164:225-236

Andersen T R, Poulsen SE, Pagola MA, Medhus AB (2020) Geophysical mapping and 3D geological modelling to support urban planning: a case study from Vejle, Denmark. J Appl Geophys, 104130.

Annan AP (2001) Ground-penetrating radar workshop notes. Sensors and Software Inc, Mississauga, ON, Canada, $192 \mathrm{pp}$

Asrat A, Zwoliński Z (2012) Geoheritage: from geoarchaeology to geotourism. Quaestiones Geographicae 31(1):5-6

Basile V, Carrozzo MT, Negri S, Nuzzo L, Quarta T, Villani AV (2000) A ground-penetrating radar survey for archaeological investigations in an urban area (Lecce, Italy). J Appl Geophys 44(1):15-32

Bathrellos GD (2007) An overview in urban geology and urban geomorphology. Bull Geol Soc Greece 40(3):1354-1364

Bizzarri R, Melelli L, Cencetti C (2018) Archaeo-geosites in urban areas: a case study of the Etruscan Palazzone Necropolis (Perugia, Central Italy). Alp Mediterr Quat 31:1-12

Blöschl G, Hall J, Viglione A, Perdigão RA, Parajka J, Merz B et al (2019) Changing climate both increases and decreases European river floods. Nature 573(7772):108-111

Booth AD, Linford NT, Clark RA, Murray T (2008) Three-dimensional, multi-offset ground-penetrating radar imaging of archaeological targets. Archaeol Prospect 15:93-112. https://doi.org/10.1002/arp.327

Bottari C, Aringoli D, Carluccio R, Castellano C, D'Ajello CF, Gasperini M, Materazzi M, Nicolosi I, Pambianchi G, Pieruccini P, Sepe V, Urbini S, Varazi F (2017) Geomorphological and geophysical investigations for the characterization of the Roman Carsulae site (Tiber basin, Central Italy). J Appl Geophys 143:74-85. https:// doi.org/10.1016/j.jappgeo.2017.03.021

Brandolini P, Faccini F, Paliaga G, Piana P (2017) Urban geomorphology in coastal environment: man-made morphological changes in a seaside tourist resort (Rapallo, Eastern Liguria, Italy). Quaestiones Geographicae 36(3):97-110

Brandolini P, Faccini F, Paliaga G, Piana P (2018) Man-made landforms survey and mapping of an urban historical center in a coastal Mediterranean environment. Geogr Fis Din Quat 41:23-34

Brigante R, Dominici D, Fastellini G, Radicioni F, Stoppini A (2009) Confronto e integrazione fra tecniche geomatiche per la documentazione e il monitoraggio dei beni culturali. Atti della XIII Conferenza Nazionale ASITA, Bari, Dicembre 2009:537-542 ISBN: 9788890313226

Bristow CS, Jol HM (2003) GPR in sediments: advice on data collection, basic processing and interpretation, a good practice guide. In: Ground penetrating radar in sediments (Eds C.S. Bristow and H.M. Jol). Geol Soc Spec Publ 211:1-7

Campana S, Piro S (2008) Seeing the unseen. CRC Press, London, Geophysics and landscape archaeology
Capizzi P, Martorana R, Messina P, Cosentino P (2012) Geophysical and geotechnical investigations to support the restoration project of the Roman 'Villa del Casale', Piazza Armerina, Sicily, Italy. Near Surf Geophys 10:145-160. https://doi.org/10.3997/1873-0604.2011038

Cappadonia C, Di Maggio C, Agate M, Agnesi V (2020) Geomorphology of the urban area of Palermo (Italy). J Maps 16(2):274-284

Carlino S (2019) Volcanoes and risk. In Neapolitan volcanoes. Springer, Cham. pp. 179-274

Casas A, Cosentino PL, Fiandaca G, Himi M, Macias JM, Martorana R, Muñoz A, Rivero L, Sala R, Teixell I (2018) Non-invasive geophysical surveys in search of the Roman temple of Augustus under the Cathedral of Tarragona (Catalonia, Spain): a case study. Surv Geophys 39:1107-1124. https://doi.org/10.1007/s10712-018 9470-6

Cencetti C, Cecconi M, Melelli L (2019) Il progetto SILENE Un SIstema Lidar per l'Esplorazione della NEcropoli del Palazzone. Culture Territori Linguaggi 15, ISBN 9788894269789, http://www.ctl. unipg.it/issues/CTL 15.pdf

Cenciaioli L (1991) Cunicoli di drenaggio a Perugia. Gli Etruschi maestri di idraulica, pp 97-104.

Cenciaioli L (2017) La città di Perugia in epoca etrusca: l'area centrale del polo urbano. In: Binazzi G (ed) Il pozzo etrusco alle origini dell'insediamento urbano di Perugia, pp. 41-65.

Chaparro JCM (2020) Identifying and mapping the risk of rockfall and landslide on roads and urban areas. In: Chaparro M, Carlos J (eds) Mapping the risk of flood, mass movement and local subsidence. Springer, Cham, pp 23-39

Conejo-Martín MA, Herrero-Tejedor TR, Lapazaran J, Perez-Martin E, Otero J, Prieto JF, Velasco J (2015) Characterization of cavities using the GPR, LIDAR and GNSS techniques. Pure Appl Geophys 172:3123-3137. https://doi.org/10.1007/s00024-0140985-6

Conyers LB (2016) Ground-penetrating radar for archaeology, First Edition. Lawrence B. Conyers (C) 2016 John Wiley \& Sons, Ltd. Published 2016 by John Wiley \& Sons, Ltd, 160 pp.

Daniels DJ (2004) Ground penetrating radar (radar, sonar and navigation). IEE Press, Institution of Engineering and Technology, London, $752 \mathrm{pp}$

Davis JL, Annan AP (1989) Ground penetrating radar for high resolution mapping of soil and rock stratigraphy. Geophys Prospect 37:531551

Deiana R, Leucci G, Martorana R (2018) New perspectives on geophysics for archaeology: a special issue. SurvGeophys 39:1035-1038. https://doi.org/10.1007/s10712-018-9500-4

Del Monte M (2017) Aeternae Urbis geomorphologia - Geomorphology of Rome. In: Marchetti M, Sodati M (eds) Landscapes and landforms of Italy. Springer, Cham, pp 339-350

Del Monte M, Fredi P, Pica A, Vergari F (2013) Geosites within Rome City center (Italy): a mixture of cultural and geomorphological heritage. Geogr Fis Din Quat 36(2):241-257. https://doi.org/10.4461/ GFDQ.2013.36.0

Del Monte M, D’Orefice M, Luberti GM, Marini R, Pica A, Vergari F (2016) Geomorphological classification of urban landscapes: the case study of Rome (Italy). J Maps 12(1):178-189

Diamanti N, Annan AP (2019) Understanding the use of groundpenetrating radar for assessing clandestine tunnel detection. Lead Edge 38(6):453-459

Dowling RK (2013) Global geotourism-an emerging form of sustainable tourism. Czech J Tour 2(2):59-79

Doyle MR (2016) From hydro/geology to the streetscape: evaluating urban underground resource potential. Tunn Undergr Space Technol 55:83-95

Ercoli M, Brigante R, Radicioni F, Pauselli C, Mazzocca M, Centi G, Stoppini A (2016) Inside the polygonal walls of Amelia (Central Italy): a multidisciplinary data integration, encompassing geodetic 
monitoring and geophysical prospections. J Appl Geophys 127:3144

Ercoli M, Di Matteo L, Pauselli C, Mancinelli P, Frapiccini S, Talegalli L, Cannata A (2018) Integrated GPR and laboratory water content measures of sandy soils: from laboratory to field scale. Constr Build Mater 159:734-744. https://doi.org/10.1016/j.conbuildmat. 2017.11.082

Ercoli M, Pauselli C, Forte E, Di Matteo L, Mazzocca M, Frigeri A, Federico C (2012) A multidisciplinary geological and geophysical approach to define structural and hydrogeological implications of the Molinaccio spring (Spello, Italy). J Appl Geophys 77:72-82

Ercoli M, Pauselli C, Frigeri A, Forte E, Federico C (2013) Geophysical paleoseismology through high resolution GPR data: a case of shallow faulting imaging in Central Italy. J Appl Geophys 90:27-40. https://doi.org/10.1016/j.jappgeo.2012.12.001

Gaballah M, Grasmueck M, Sato M (2018) Characterizing subsurface archaeological structures with full resolution 3D GPR at the early dynastic foundations of Saqqara necropolis, Egypt. Sens Imaging 19:23. https://doi.org/10.1007/s11220-018-0209-8

Gisotti G (2016) La fondazione delle città. Le scelte insediative da Uruk a New York, Carocci edn. Roma, Italy, p 559

Gizzi FT, Loperte A, Satriani A, Lapenna V, Masini N, Proto M (2010) Georadar investigations to detect cavities in a historical town damaged by an earthquake of the past. Adv Geosci 24:15-21

Goodman D, Piro S (2013) GPR remote sensing in archaeology. Springer Science \& Business Media. (ISBN: 978-3-642-31856-6)

Grassi S, Imposa S, Patti G, Boso D, Lombardo G, Panzera F (2019) Geophysical surveys for the dynamic characterization of a cultural heritage building and its subsoil: the S. Michele Arcangelo Church (Acireale, eastern Sicily). J Cult Herit 36:72-84. https://doi.org/10. 1016/j.culher.2018.09.015

Habibi T, Ponedelnik AA, Yashalova NN, Ruban DA (2018) Urban geoheritage complexity: evidence of a unique natural resource from Shiraz City in Iran. Res Policy 59:85-94

Hasan SA, Hazem G (2020) Using geomatics methodology to study gentrification indicators of urban heritage districts case study (Alkurd and Altaees neighbourhood) in Babylon Province-Iraq. MS\&E 737(1):012241

Huggenberger P, Epting J (Eds.) (2011) Urban geology: process-oriented concepts for adaptive and integrated resource management. Springer Science \& Business Media.

Imposa S, Grassi S, Patti G, Boso D (2018) New data on buried archaeological ruins in Messina area (Sicily-Italy) from a ground penetrating radar survey. J Archaeol Sci Rep 17:358-365. https://doi.org/10. 1016/j.jasrep.2017.11.031

Jol HM (2009) Ground penetrating radar: theory and applications. Elsevier, p 544

Karrow PF, White OL (1998) Urban geology of Canadian cities; Special Paper 42; Geological Association of Canada: St. John's, NL, Canada, p 500. isbn:0-919216-62-5

Kubalíková L, Kirchner K, Kuda F, Bajer A (2020) Assessment of urban geotourism resources: an example of two geocultural sites in Brno, Czech Republic. Geoheritage 12(1):7

Kumar K, Singh RM (2020) Application of geomatics for drainage network delineation for an urban city. In: Applications of geomatics in civil engineering. Springer, Singapore pp, pp 263-272

Leckebusch J (2003) Ground-penetrating radar: a modern threedimensional prospection method. Archaeol Prospect 10:213-240. https://doi.org/10.1002/arp.211

Legget RF (1973) Cities and geology. McGraw-Hill: New York, NY, USA pp. 624
Legget RF (1969) Urban geology. Canadian Building Digest, 113; National Research Council: Ottawa, ON, Canada, pp. 4

Leucci G (2006) Contribution of ground penetrating radar and electrical resistivity tomography to identify the cavity and fractures under the main Church in Botrugno (Lecce, Italy). J Archaeol Sci 33:1194 1204. https://doi.org/10.1016/j.jas.2005.12.009

Leucci G, Negri S (2006) Use of ground penetrating radar to map subsurface archaeological features in an urban area. J Archaeol Sci 33: 502-512. https://doi.org/10.1016/j.jas.2005.09.006

Lewin J, Macklin MG (2014) Marking time in geomorphology: should we try to formalise an Anthropocene definition? Earth Surf Process Landf 39(1):133-137

Liu Z, Cai Y, Wang S, Lan F, Wu X (2020) Small and medium-scale river flood controls in highly urbanized areas: a whole region perspective. Water 12(1):182

Lorenzo H, Hernández MC, Cuéllar V (2002) Selected radar images of man-made underground galleries. Archaeological Prospection. Archaeol Prospect 9(1):1-7

Luberti GM, Vergari F, Pica A, Del Monte M (2019) Estimation of the thickness of anthropogenic deposits in historical urban centres: an interdisciplinary methodology applied to Rome (Italy). The Holocene 29(1):158-172

Luberti GM, Del Monte M (2020) Landscapes and landforms connected with anthropogenic processes over three millennia: the Servian Walls at the Esquiline Hill (Rome, Italy). The Holocene 30(12): $1817-1832$

Malfitana D, Leucci G, Fragalà G, Masini N, Scardozzi G, Cacciaguerra G, Santagati C, Shehi E (2015) The potential of integrated GPR survey and aerial photographic analysis of historic urban areas: a case study and digital reconstruction of a Late Roman villa in Durrës (Albania). J Archaeol Sci Rep 4:276-284. https://doi.org/10.1016/j. jasrep.2015.09.018

Marker BR (2016) Urban planning: the geoscience input. Geological Society, London, Engineering Geology Special Publications 27(1): $35-43$

Martinaud M, Frappa M, Chapoulie R (2004) GPR signals for the understanding of the shape and filling of man-made underground masonry. GPR 2004. Proceedings of the Tenth International Conference on Ground Penetrating Radar, pp. 439-442.

Martorana R, Capizzi P (2020) Seismic and non-invasive geophysical surveys for the renovation project of Branciforte Palace in Palermo. Archaeol Prospect:1-14. https://doi.org/10.1002/arp.1781

Mateos RM, López-Vinielles J, Poyiadji E, Tsagkas D, Sheehy M, Hadjicharalambous $\mathrm{K}$ et al (2020) Integration of landslide hazard into urban planning across Europe. Landsc Urban Plan 196:103740

Matracchi P, Radicioni F, Stoppini A, Tosi G (2019) The cathedral of S. Lorenzo in Perugia and the hypogeal spaces. Geomatic techniques for spatial investigations aimed at the knowledge and interpretation of the origin of the transept, ISPRS Annals of the Photogrammetry, Remote Sensing and Spatial Information Sciences, 42 (2/W11), 849-856, https://doi.org/10.5194/isprs-Archives-XLII-2-W11-8492019

Meju MA (2000) Geoelectrical investigation of old/abandoned, covered landfill sites in urban areas: model development with a genetic diagnosis approach. J Appl Geophys 44:115-150

Melelli L, Bizzarri R, Baldanza A, Gregori L (2016) The Etruscan "Volumni Hypogeum" archeo-geosite: new sedimentological and geomorphological insights on the Tombal complex. Geoheritage 8(4):301-314

Melelli L (2019) "Perugia upside-down": a multimedia exhibition in Umbria (Central Italy) for improving geoheritage and geotourism in urban areas. Resources 8(3):148 
Melelli L, Rosati E (2019) Una finestra sulla geologia del Colle di Perugia. La città sotterranea nella documentazione dell'archivio Rosati. Culture Territori Linguaggi 16, ISBN 9788894469707

Morris I, Cleary J, Gonciar A, Glisic B (2019) Ground penetrating radar investigation of Corvin Castle (Castelul Corvinilor), Hunedoara, Romania. Heritage 2:1316-1349

Novo A, Lorenzo H, Rial FI, Solla M (2010) Three-dimensional groundpenetrating radar strategies over an indoor archaeological site: convent of Santo Domingo (Lugo, Spain). Archaeol Prospect 17:213222

Novo A, Solla M, Montero Fenollós JL, Lorenzo H (2014) Searching for the remains of an Early Bronze Age city at Tell Qubr Abu al-'Atiq (Syria) through archaeological investigations and GPR imaging. J Cult Herit 15(5):575-579. https://doi.org/10.1016/j.culher.2013.10. 006

Núñez-Nieto X, Solla M, Novo A, Lorenzo H (2014) Three-dimensional ground-penetrating radar methodologies for the characterization and volumetric reconstruction of underground tunneling. Constr Build Mater 71:551-560. https://doi.org/10.1016/j.conbuildmat.2014.08. 083

Nuzzo L, Leucci G, Negri S, Carrozzo M, Quarta T (2002) Application of $3 \mathrm{D}$ visualization techniques in the analysis of GPR data for archaeology. Ann Geophys 45(2):321-337. https://doi.org/10.4401/ag3517

Orlando L (2013) GPR to constrain ERT data inversion in cavity searching: theoretical and practical applications in archeology. J Appl Geophys 89:35-47. https://doi.org/10.1016/j.jappgeo.2012. 11.006

Orlando L, Michetti LM, Belelli Marchesini B, Papeschi P, Giannino F (2019) Dense georadar survey for a large-scale reconstruction of the archaeological site of Pyrgi (Santa Severa, Rome). Archaeol Prospect 26:369-377. https://doi.org/10.1002/arp.1750

Palacio-Prieto JL (2014) Geoheritage within cities: urban geosites in Mexico City. Geoheritage 7:365-373

Parise M, Galeazzi C, Bixio R, Dixon M. (2013). Classification of artificial cavities: a first contribution by the UIS Commission. In Proceedings of the 16th International Congress of Speleology, 2, pp. 230-235.

Perez-Gracia V, Canas JA, Pujades LG, Clapes J, Caselles O, Garcia F, Osorio R (2000) GPR survey to confirm the location of ancient structures under the Valencian cathedral (Spain). J Appl Geophys 43(2-4):167-174

Petrelli M, Perugini D, Moroni B, Poli G (2004) Travertine, a building stone extensively employed in Umbria from Etruscan to Renaissance age: provenance determination using artificial intelligence technique. Periodico di Mineralogia 73(3):151-169

Pica A, Reynard E, Grangier L, Kaiser C, Ghiraldi L, Perotti L, Monte MD (2018) GeoGuides, urban geotourism offer powered by mobile application technology. Geoheritage 10:311-326. https://doi.org/10. 1007/s12371-017-0237-0

Pica A, Vergari F, Fredi P, Del Monte M (2016) The Aeterna Urbs geomorphological heritage (Rome, Italy). Geoheritage 8:31-42. https://doi.org/10.1007/s12371-015-0150-3

Pipan M, Baradello L, Forte E, Prizzon A, Finetti I (1999) 2-D and 3-D processing and interpretation of multi-fold ground penetrating radar data: a case history from an archaeological site. J Appl Geophys 41(2-3):271-292. https://doi.org/10.1016/S0926-9851(98)00047-0

Piro S, Haynes I, Liverani P, Zamuner D (2017) GPR investigation to map the subsoil of the St. John Lateran Basilica (Rome, Italy). Bollettino di Geofisica Teorica ed Applicata 58(4)
Premangshu C, Rahul M (2019) Geoarchaeosites for geotourism: a spatial analysis for Rarh Bengal in India. Geo J Tour Geosites 25(2):543554

Puente I, Solla M, Lagüela S, Sanjurjo-Pinto J (2018) Reconstructing the Roman site "AquisQuerquennis" (Bande, Spain) from GPR, TLiDAR and IRT data fusion. Remote Sens 10(3):379

Pueyo-Anchuela Ó, DiarteBlasco P, García Benito C, Casas Sainz AM, Pocoví Juan A (2016) Geophysical and archaeological characterization of a modest Roman villa: methodological considerations about progressive feedback analyses in sites with low geophysical contrast. Archaeol Prospect 23:105-123. https://doi.org/10.1002/arp. 1529

Radicioni F, Stoppini A, Tosi G, Marconi L (2020) Necropolis of Palazzone in Perugia: integrated geomatic techniques for a geomorphological analysis. In Alvioli $\mathrm{M}$ et al (Eds) Proceedings of the geomorphometry 2020 conference, pp. 67-70, https://doi.org/10. 30437/GEOMORPHOMETRY2020_18

Ramírez-Blanco M, García-García F, Rodríguez-Abad I, Martínez-Sala R, Benlloch J (2008) Ground-penetrating radar survey for subfloor mapping and analysis of structural damage in the Sagrado Corazón de Jesús Church, Spain. Archaeol Prospect 15:285-292. https://doi. org/10.1002/arp.341

Reynard E, Pica A, Coratza P (2017) Urban geomorphological heritage. An overview. Quaestiones geographicae 36(3): 7-20.

Ribolini A, Bini M, Isola I, Coschino F, Baroni C, Salvatore MC, Zanchetta G, Fornaciari A (2017) GPR versus geoarchaeological findings in a complex archaeological site (Badia Pozzeveri, Italy). Archaeol Prospect 24:141-156. https://doi.org/10.1002/arp.1561

Ristic A, Govedarica M, Pajewski L, Vrtunski M, Bugarinović Ž (2020) Using ground penetrating radar to reveal hidden archaeology: the case study of the Württemberg-Stambol Gate in Belgrade (Serbia) sensors 20: 607, https://doi.org/10.3390/s20030607

Rodrigues ML, Machado CR, Freire E (2011) Geotourism routes in urban areas: a preliminary approach to the Lisbon geoheritage survey. Geo J Tour Geosites 8(2):281-294

Rosenbaum MS, McMillan AA, Powell JH, Cooper AH, Culshaw MG, Northmore KJ (2003) Classification of artificial (man-made) ground. Eng Geol 69(3-4):399-409. https://doi.org/10.1016/ S0013-7952(02)00282-X

Sala R, Ortiz H, Sanmartí J, Garcia-Garcia E, Belarte MC, Noguera J, Morer J, Ble E, Pou J, Asensio D, Jornet R (2020) Geophysical survey of the Iberian site (seventh-third centuries BC) of Masies de Sant Miquel (Catalonia, Spain). Interpretative challenges of geophysical data of an Iberian town. Archaeol Prospect 27:181-199. https://doi.org/10.1002/arp.1765

Schuhmacher S, Boehm J (2005) Georeferencing of terrestrial laserscanner data for applications in architectural modelling. International Archives of Photogrammetry. Remote Sens Spat Inf Sci 36

Siegel FR (2020) Coastal city flooding. In: Adaptations of coastal cities to global warming, sea level rise, climate change and endemic hazards. Springer, Cham, pp 27-34

Stopponi S (1991) Nuove osservazioni sul pozzo Sorbello e sul suo inserimento nel tessuto urbano di Perugia antica. In: Bergamini M. (ed) Gli Etruschi Maestri di Idraulica, 235-246.

Teunissen P, Montenbruck O (eds.) (2017) Springer handbook of Global Navigation Satellite Systems. Springer, Springer International Publishing, https://doi.org/10.1007/978-3-319-42928-1

Thornbush M (2015) Geography, urban geomorphology and sustainability. Area 47(4):350-353

Toschi I, Nocerino E, Remondino F (2017) Geomatics makes smart cities a reality. GIM Int 31(10):25-27 
Trinks I, Karlsson P, Biwall A, Hinterleitner A (2010) Mapping the urban subsoil using ground penetrating radar - challenges and potentials for archaeological prospection. ArcheoSciences 33 (suppl.)

Trinks I, Hinterleitner A, Neubauer W, Nau E, Löcker K, Wallner M, Gabler M, Filzwieser R, Wilding J, Schiel H, Jansa V, Schneidhofer P, Trausmuth T, Sandici V, Ruß D, Flöry S, Kainz J, Kucera M, Vonkilch A, Tencer T, Gustavsen L, Kristiansen M, Bye-Johansen LM, Tonning C, Zitz T, Paasche K, Gansum T, Seren S (2018) Large-area high-resolution ground-penetrating radar measurements for archaeological prospection. Archaeol Prospect 25:171-195. https://doi.org/10.1002/arp.1599

Tucci G, Bonora V (2015) Geomatics and management of at-risk cultural heritage. Rendiconti Lincei 2(1):105-114. https://doi.org/10.1007/ s12210-015-0427-0

Verdonck L (2016) Detection of buried Roman wall remains in groundpenetrating radar data using template matching. Archaeol Prospect 23:257-272. https://doi.org/10.1002/arp.1540

Yilmaz S, Oksum E, Cakmak O, Dogan O, Tekelioğlu E (2018) Preliminary results of an integrated archaeo-geophysical survey on the basis of ancient finds unearthed by an illegal excavation at KılıçÖren site (Isparta, Turkey). Archaeol Prospect 25:197-207. https://doi.org/10.1002/arp.1702

Wunderlich T, Wilken D, Andersen J, Rabbel W, Zori D, Kalmring S, Byock J (2015) On the ability of geophysical methods to image medieval turf buildings in Iceland. Archaeol Prospect 22:171-186. https://doi.org/10.1002/arp.1506

Zagozdzon PP, Zagozdzon KD (2016) Some aspects of geotourism in Poland - underground facilities and urban geotourism. Prz Geol 64: 739-750

Zhao W, Forte E, Fontana F, Pipan M, Tian G (2018) GPR imaging and characterization of ancient Roman ruins in the Aquileia Archaeological Park, NE Italy, Measurement, 113:161-171, https://doi.org/10.1016/j.measurement.2017.09.004

Zheng H, Guo L, Liu J, Zheng T, Deng Z (2020) Evaluating seismic risk in small and medium-sized cities with the modified vulnerability index method, a case study in Jiangyou City, China. Bull Earthq Eng 18(4):1303-1319 